\title{
Diversity and time-series analyses of Caribbean deep-sea coral and sponge assemblages on the tropical island slope of Isla de Roatán, Honduras
}

\author{
Peter J. Etnoyer ${ }^{1} \mathbb{D}$. Charles G. Messing ${ }^{2} \cdot$ Karl A. Stanley $^{3} \cdot$ Tomasz K. Baumiller $^{4} \cdot$ Kate Lavelle $^{5} \cdot$ Thomas C. Shirley $^{6}$
}

Received: 15 September 2021 / Revised: 15 December 2021 / Accepted: 17 December 2021 / Published online: 13 January 2022

This is a U.S. government work and not under copyright protection in the U.S.; foreign copyright protection may apply 2022

\begin{abstract}
Shore-based submersible operations, from 2006 to 2020, have allowed us to examine megabenthic assemblages along the island margin of Isla de Roatán from depths of about 150 to $750 \mathrm{~m}$, including repeated observations of the same organisms. These dives were used to photo-document a diverse benthic assemblage and observe the health and condition of the sessile fauna in a well-explored but relatively undocumented area of the Mesoamerican Reef. Samples were collected by dip net, and some dives profiled the water column chemistry in the year 2011. The deep-sea coral assemblage observed off Roatan exhibits high abundance and diversity. The sessile habitat-forming taxa consist primarily of at least 20 different octocorals (e.g., Plexauridae, Primnoidae, Coralliidae, Isididae, and Ellisellidae) and 20 different sponges each (Demospongiae and Hexactinellida), with several known and unknown taxa of Zoantharia, Antipatharia (Bathypathes spp), and Scleractinia (e.g., Desmophyllum pertusum, Dendrophyllia alternata, Madracis myriaster, and solitary taxa). Crinoidea were also abundant and diverse, represented by at least nine species. Epifaunal assemblages associated with corals include at least 24 macroinvertebrate species dominated by Asteroschema laeve (Ophiuroidea) and Chirostylus spp. (Decapoda: Anomura). Repeated observations of a few large octocoral colonies over many years illustrate patterns of predation, recolonization, and epibiont host fidelity, including a 14-year record of decline in a plexaurid octocoral (putatively Paramuricea sp.) and loss of its resident ophiuroids. The shore-based submersible provides a practical and relatively inexpensive platform from which to study coral and sponge assemblages on a deep tropical island slope. The deep-sea coral gardens are likely to harbor new species and new discoveries if more samples can be acquired and made available for taxonomic research.
\end{abstract}

Keywords Benthic ecology $\cdot$ Mesoamerican Reef $\cdot$ Gorgonian $\cdot$ Octocoral $\cdot$ Crinoid $\cdot$ Submersible $\cdot$ Corallivory $\cdot$ Predation

Communicated by B. W. Hoeksema

Peter J. Etnoyer

peter.etnoyer@noaa.gov

1 NOAA National Centers for Coastal Ocean Science, Hollings Marine Laboratory, Charleston, SC, USA

2 Department of Marine and Environmental Sciences, Nova Southeastern University, Dania Beach, FL, USA

3 Roatan Institute for Deepsea Exploration, Roatán, Honduras

4 Museum of Paleontology and Department of Earth and Environmental Sciences, University of Michigan, Ann Arbor, MI, USA

5 Texas Commission On Environmental Quality, Austin, TX, USA

6 Dept. of Life Sciences and Harte Research Institute, Texas A\&M University-Corpus Christi, Corpus Christi, TX, USA

\section{Introduction}

Our knowledge and understanding of the ecology, physiology, biodiversity, and conservation of habitat-forming, deepand cold-water coral and sponge assemblages has broadened substantially over the last two decades (e.g., Freiwald et al. 2004; Davies et al. 2008; Davies and Guinotte 2011; Roberts et al. 2006; Dahl et al. 2012; Larsson et al. 2013a, b; Cathalot et al. 2015; Hourigan et al. 2017; Quattrini et al. 2017; Hebbeln et al. 2019). However, the majority of research has been carried out at higher latitudes in temperate seas, leaving assemblages at subtropical and tropical latitudes less well-investigated (e.g., Messing et al. 1990; Grasmueck et al. 2006; Reed et al. 2006, 2013; Demopoulos et al. 2014; Ross et al. 2015; Ramiro-Sánchez et al. 2019). Fewer studies have incorporated time-series observations of the same sites and organisms over extended periods (e.g., Brooke and 
Young 2009; Kahn et al. 2012; Kuhnz et al. 2014; Purser 2015; Osterloff et al. 2019). The increasingly widespread use of privately funded research submersibles (e.g., OceanX, Nekton Foundation, Curasub) offers the opportunity to conduct and expand in situ deep-sea time-series investigations. Here we report the preliminary results of ecological observations made using a privately owned submersible over a 14-year period.

Isla de Roatán, off the north coast of Honduras, Central America, lies in the western Caribbean Sea at the southern end of the Mesoamerican Reef (Fig. 1), on the southern margin of a left-lateral strike-slip fault, the Swan Islands Transform Fault, near the west end of the Cayman Trough (Rosencrantz and Mann 1991). The transform fault is part of the boundary between the North American and Caribbean plates. The deep island margin supports a high diversity of geologic and topographic features, beginning with the deep reef wall, and, below it, numerous slump blocks and a wide variety of outcrops and escarpments-chiefly limestone above $\sim 400-450 \mathrm{~m}$ and basalt below-both exposed and sediment veneered and accompanied by extensive areas of unconsolidated sediment.

This is the first detailed report of living deep-sea coral and sponge assemblages from Isla de Roatán and from the Mesoamerican Barrier Reef in general. The data discussed herein grew out of the felicitous confluence of independent projects that used the same research platform, the submersible Idabel, owned and piloted by coauthor Karl Stanley and based at the Roatan Institute for Deepsea Exploration, West End, Roatán. The submersible Idabel has been used previously by marine researchers to study the growth of deep-sea Crinoidea (e.g., Syverson et al. 2014), genetics of slit-shell gastropods (J. Harasewych, Smithsonian Institution, National Museum of Natural History (NMNH), pers. comm.), and to describe new fish species (Lipogramma idabeli) named in honor of the sub (Tornabene et al. 2018).

\section{Materials and methods}

Submersible Idabel is 4-m long, 2.0-m wide, 2.1-m tall, with space for the pilot and two observers (maximum capacity $220 \mathrm{~kg}$ ), a $1.05-\mathrm{m}$ diameter observation compartment with a 76-cm diameter viewport, and a depth rating of $915 \mathrm{~m}$ (Fig. 2). The dock where Idabel is based is $250 \mathrm{~m}$ from the trench wall, which eliminates the need for a surface support vessel for most dives. The lithium batteries in the sub allow for a $16 \mathrm{~km}$ range. The sub was towed as far as $5 \mathrm{~km}$, from its base at Half Moon Bay to Anthony's Key Reef (see Fig. 1).

Three field expeditions using Idabel were conducted in 2010 and 2011. These were called Deep Coral and Associated Species Taxonomy (DeepCAST) expeditions (Etnoyer et al. 2011). Over the course of 2 years, thirteen submersible dives were made at eight different locations (Fig. 1). Of these, eight dives proved useful for image-based analysis of species distribution (Table 1). In addition, a brief multibeam survey was conducted by RV Falkor on July 9-10, 2013, to map the steep terrain from 150 to $1500 \mathrm{~m}$ depth (NOAA 2013). Subsequent dives were conducted to study the ecology of Crinoidea (Veitch and Baumiller 2021). Nineteen dives focused on crinoids were made from June 2012 to June 2016 in the general vicinity of previous dives. Some dives repeated photo observations of large sea fan corals from previous years. All the above data resources are assembled
Fig. 1 Submersible dive sites off Isla Roatán, Honduras. Dives were made at these and unnamed sites in the same region between 2008 and 2020. Map created in ArcGIS 10.4 , using bathymetry data from RV Falkor FK-008T (see NOAA 2013)

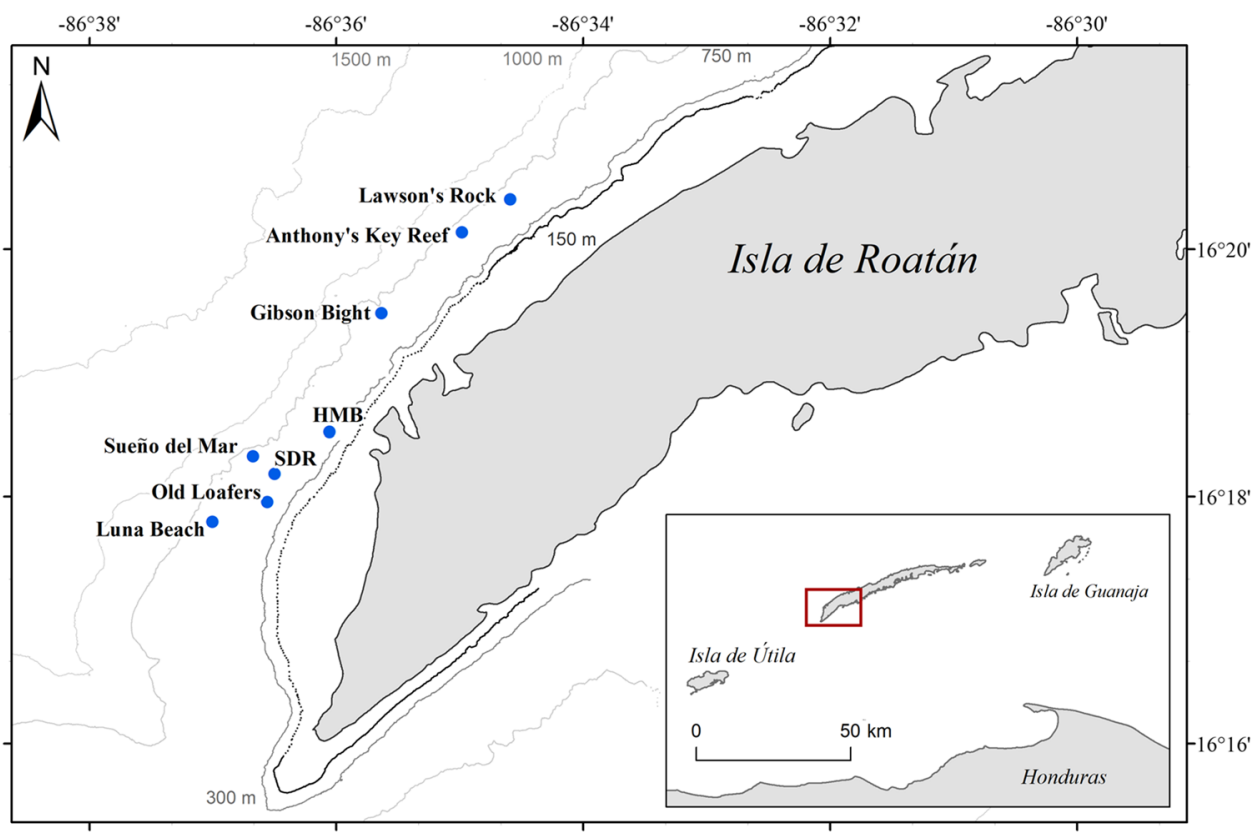




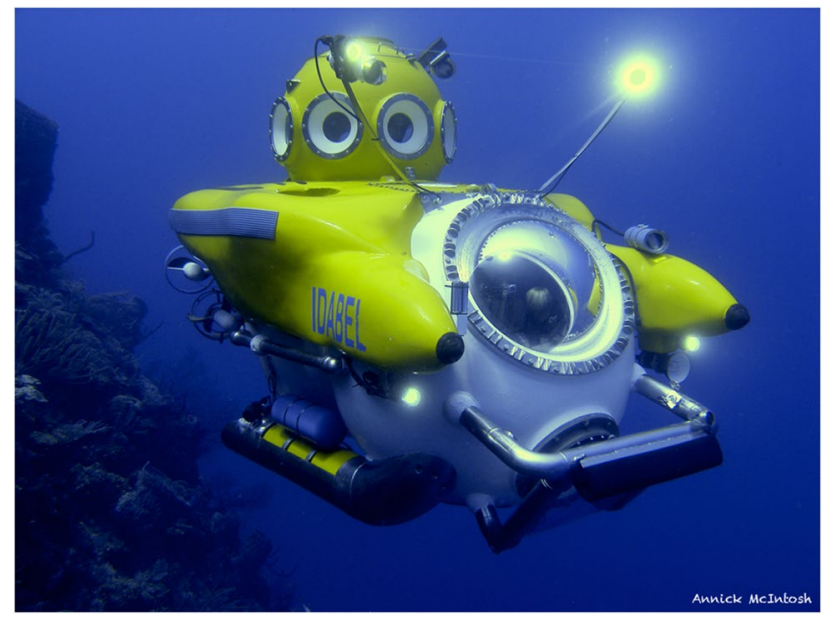

Fig. 2 The Idabel submersible was used to explore dive sites off Isla Roatán, Honduras. Photo courtesy of Annick McIntosh

here to illustrate the diversity of sessile benthic epifauna, in a relatively pristine deep-sea environment with remarkable proximity to shore (within $2 \mathrm{~km}$ ).

DeepCAST I was a 3-day reconnaissance in August 2010. DeepCAST II conducted quantitative photo and video transects of deep coral and sponge habitats at six independent sites in May 2011 with observations spanning a depth range of 60-670 m (Etnoyer et al. 2011). DeepCAST III conducted quantitative dives at three additional sites in December 2011 to a maximum depth of $700 \mathrm{~m}$; a fourth chiefly shallower dive is not discussed here (Lavelle 2012).

Beginning with DeepCAST II, the sub was outfitted with laser scale, cameras, an oceanographic sensor, and a dip net for sample collections. The dip net consisted of a $14-\mathrm{ft}$ (4.3-m) pole mounted to Idabel's port side rail with a steel ring $\sim 20 \mathrm{~cm}$ across at its front end with a long mesh bag weighted with stones to make it hang. A Sony HDR-HC9 video camera mounted on the forward rail was operated continuously throughout each 4 to 6-h dive. Interior cameras included a Sony HDR-HC9 video camera on a tripod and a Canon SLR still camera, with exterior strobes synchronized to the camera. The still camera operator took $\sim 1$ photo $\mathrm{min}^{-1}$ with particular attention to coral and sponge colonies and included both wide and medium angle shots of the seafloor. The video operator recorded continuous high-definition video on 1-h-long MiniDV tapes. A housing containing a pair of scaling lasers $10-\mathrm{cm}$ apart was also mounted on the forward rail. Both camera operators attempted to frame images to include the pair of green laser dots projected from the submersible onto the seafloor.

A Sea-Bird SEACAT 19 conductivity-temperature-depthoxygen (CTD-O) sensor with a supplementary $\mathrm{pH}$ sensor was mounted on Idabel's starboard side rail to generate continuous, along-track water chemistry profiles for each dive, especially around Desmophyllum pertusum reefs (formerly Lophelia pertusa; Addamo et al. 2016). The unit was activated before each dive, and data were downloaded on recovery. The unit did not record for the entire transit on most dives, but one complete track was recorded. All watches and cameras were synchronized. Divers produced brief summaries of each dive with dive chronologies providing information on dive start time, start coordinates, maximum and minimum depths, habitat, debris, and animals observed (see Etnoyer et al. 2011 for details).

A few biological samples were also collected in deep water with a baited trap-a green plastic basket baited with lionfish heads, wrapped in mesh fabric, and weighted with rebar. A yellow rope threaded through a block of buoyant syntactic foam and attached to the basket created a retrieval loop. The trap was successfully retrieved using a long shepherd's crook device mounted on the port side rail in place
Table 1 List of locations explored by Idabel submarine. Dives that yielded images for analysis of species distributions are indicated by "yes." Start positions are approximated based on depth and shore-based references

\begin{tabular}{lllllllll}
\hline Year & Month & Dive & Locality & Code & Depth & Lat & Long & Analysis \\
\hline 2010 & May & 1 & Old Loafers & OLS & 700 & na & na & No \\
2010 & May & 2 & Three King* & AKR & 700 & 16.349 & -86.568 & No \\
2010 & May & 3 & Shark Reef & na & 750 & na & na & No \\
2011 & Aug & 1 & Luna Beach & LBE & 643 & 16.297 & -86.617 & Yes \\
2011 & Aug & 2 & Sueño Del Mar 1 & SDM & 655 & 16.306 & -86.611 & Yes \\
2011 & Aug & 3 & Half Moon Bay & HMB & 465 & 16.309 & -86.601 & No \\
2011 & Aug & 4 & Anthony's Key Reef & AKR & 640 & 16.336 & -86.583 & Yes \\
2011 & Aug & 5 & Lawson's Rock & LWR & 613 & 16.339 & -86.571 & Yes \\
2011 & Aug & 6 & Old Loafers & OLS & 375 & 16.300 & -86.610 & Yes \\
2011 & Dec & 1 & Sueño Del Mar 2 & SDR & 454 & 16.303 & -86.608 & Yes \\
2011 & Dec & 3 & Gibson Bight & GBB & 701 & 16.325 & -86.595 & Yes \\
2011 & Dec & 4 & Half Moon Bay & HMB & na & 16.309 & -86.601 & Yes \\
\hline
\end{tabular}

Depth is in meters

*Three Kings was renamed Anthony's Key Reef 
of the dip net. Coral collections were permitted by Instituto Nacional de Conservación y Desarrollo Forestal, Áreas Protegidas, y Vida Silverstre, Resolución DE-MP-074-2011.

Nineteen dives from June 2012 to June 2016 used interior mounted and handheld Canon SLR and GoPro cameras, with exterior-mounted scaling lasers on some dives. The maximum depth was $640 \mathrm{~m}$ with most observations made between 150 and $400 \mathrm{~m}$. For collecting small sessile crinoids, a small steel blade was welded to the forward end of the dip net ring to permit scraping along with hard substrates, and the net was lined with finer material.

The analysis of species distribution for corals reviewed video and images from select dives that met criteria where depth and location were known, still images were semi-periodic, and notes were available. These 8 dives are hereafter referred to as "quantitative dives" (see Table 1). The sponge and crinoid observations are based on a larger set of observations from "nonquantitative dives" in 2012-2016. For the quantitative dives in 2010 and 2011, the on-bottom video was reviewed for counts of large $(>10 \mathrm{~cm})$ habitat-forming corals. Some rare, unidentifiable, and hyperabundant taxa (e.g., Stichopathes) were excluded. Depth zones in Table 2 are based upon discontinuities in faunal distributions identified using a one-way incomplete blocking design ANOVA (not discussed here) (Lavelle 2012).

Still images were reviewed independently for a more general census of presence and absence of all taxa, and attribution of depth ranges. Taxonomic identifications of corals and sponges were made nearly exclusively using these still images except in the case of a few fragile coral species that could be collected (i.e., Hemicorallium niobe (Bayer, 1964), Madracis myriaster (Milne Edwards \& Haime, 1850), Desmophyllum pertusum (Linnaeus, 1758) (formerly Lophelia pertusa). As such, many coral and sponge taxa were identified at higher levels (family or genus) based upon gross morphology, using online image references, and working in consultation with experts (see Acknowledgements). The crinoids were identified based upon tissue samples collected in 2012-2016, so their scientific names are more specific.

\section{Results}

Dives recorded at least 32 morphological species (i.e., phenotypes) of deep-water corals (6 colonial Scleractinia, 17 Octocorallia, 9 Antipatharia) at depths of $\sim 150 \mathrm{~m}$ or greater. Of the deep taxa, 16 were recorded during quantitative dive transects (4 Scleractinia, 8 Octocorallia, 4 Antipatharia) (Table 2). Taxa recorded exclusively shallower than $150 \mathrm{~m}$ included Swiftia exserta and Nicella spp. (both Octocorallia). Of the two relatively shallow $(<165 \mathrm{~m})$ colonial scleractinians observed during nonquantitative dives, Madracis myriaster was common, whereas only a few colonies of Madrepora carolina (Pourtalès, 1871) were observed (Fig. 3). Of the deeperwater taxa, Dendrophyllia alternata Pourtalès, 1880, occurred in substantial groves and in two color forms. Desmophyllum pertusum occurred as more or less individual colonies, sometimes as thickets over $3-5 \mathrm{~m}$ in diameter, other times as living colonies on dead branches attached to vertical or overhanging substrates, or as scattered small living branches on a substantial accumulation of dead branches. A single colony of Enallopsammia rostrata (Pourtalès, 1878) was recorded at $588 \mathrm{~m}$. Solitary cup corals, including Javania sp., were observed but not examined in detail.

Among octocorals, two large Plexauridae sea fans-one yellow, one purple-were most widespread and abundant (Table 2, Fig. 4). Colony sizes ranged from 40 to $160 \mathrm{~cm}$ in height and width. These have been attributed to Paramuricea due to their resemblance to similar colonies in the Gulf of Mexico (Doughty et al. 2014). Some steep-walled areas were characterized by large numbers of Primnoidae (subfamily Calytrophorinae: presumably Narella and Paracalytrophora) with dozens of colonies over 1-m tall, some up to $1.6 \mathrm{~m}$ in height. The precious octocoral Hemicorallium niobe also occurred in small aggregations on mixed substrates near $600 \mathrm{~m}$ depth, with colony sizes $40-80 \mathrm{~cm}$ in width. In shallower waters, on steep walls near $150 \mathrm{~m}$ depth, we observed large Nicella sp. (Etnoyer et al. 2011), the largest $\sim 2.5 \mathrm{~m}$ across. Among antipatharians, both fanshaped taxa and orange whip corals (Stichopathes sp.) were common (Fig. 5), whereas large pinnate Bathypathes corals were rare. Other cnidarians included a few zoantharian taxa (e.g., Parazoanthus spp.), all overgrowing the axes of other anthozoans; actinians (e.g., Alicia mirabilis Johnson, 1861, Liponema sp., and Sagartiidae), and stylasterid hydrocorals. Although the latter are usually treated broadly as corals, they have not been included here in any counts, as no morphospecies were distinguished and no colonies quantified.

The diverse and abundant sponge fauna included over 20 distinguishable morphospecies and was dominated by hexactinellids (Fig. 6), including yellow, funnel-shaped Dactylocalycidae at a surprisingly shallow depth: $131 \mathrm{~m}$. Identified hexactinellids included Iphiteon panicea Bowerbank, 1869, Dactylocalyx pumiceus Stutchbury, 1841, Vazella pourtalesii (Schmidt, 1870), two Farrea species, two corbitelline Euplectellidae species, and a rossellid forming clusters of stalked spheres. Demosponges were relatively widely scattered, although some lithistids, e.g., Corallistidae, were locally abundant. Other identified demosponges included Leiodermatium sp., Spongosorites sp., Petrosiidae, small blue encrusting Desmacellidae, Pachastrellidae, and both globular and tube-shaped Tetractinellida. Table 2 omits sponges because of uncertainties in distinguishing taxa consistently between DeepCAST sites. None were quantified. 
Table 2 List of the most common coral and crinoid taxa observed during submersible dives. Taxa with an " $\mathrm{x}$ " for abundance were present, but not counted. Totals are for taxa observed during quantitative dives only

\begin{tabular}{|c|c|c|c|c|c|c|c|c|c|c|}
\hline \multirow[t]{2}{*}{ Species } & \multirow[t]{2}{*}{ Depth range $(\mathrm{m})$} & \multicolumn{9}{|c|}{ Absolute abundance (by site) } \\
\hline & & AKR & GBB & HMB & LBE & LWR & OLS & SDM & SDR & Total \\
\hline \multicolumn{11}{|l|}{ Octocorallia } \\
\hline Acanthogorgia sp. & $625-664$ & $\mathrm{x}$ & 1 & $\mathrm{x}$ & $\mathrm{x}$ & $\mathrm{x}$ & & $\mathrm{x}$ & $\mathrm{x}$ & 1 \\
\hline Chrysogorgiidae sp. & $622-701$ & & 1 & 1 & $\mathrm{x}$ & 1 & & & & 3 \\
\hline Corallium niobe & $518-664$ & 1 & 3 & 1 & 1 & & & $\mathrm{x}$ & $\mathrm{x}$ & 6 \\
\hline Lepidisis sp. & $366-521$ & & 1 & $\mathrm{x}$ & $\mathrm{x}$ & & & & 1 & 2 \\
\hline Paramuricea sp. (purple) & $305-671$ & $\mathrm{x}$ & 2 & & 31 & 28 & 2 & 3 & 12 & 78 \\
\hline Paramuricea sp. (yellow) & $250-664$ & 1 & 2 & 16 & 16 & 11 & 3 & 2 & 30 & 81 \\
\hline Primnoidae sp. A (Calyptrophorinae) & $427-664$ & 3 & 1 & 1 & 11 & 9 & & 2 & $\mathrm{x}$ & 27 \\
\hline Primnoidae sp. B (Narella sp.) & $610-671$ & 2 & 1 & & 2 & & & & & 5 \\
\hline Nicella sp. & $150-366$ & & & & & $\mathrm{x}$ & $\mathrm{x}$ & & & \\
\hline Isidella sp. & 701 & & $\mathrm{x}$ & & & & & & & \\
\hline Isididae & $609-627$ & & & & $\mathrm{x}$ & & & & $\mathrm{x}$ & \\
\hline Anthomastus sp. & $152-189$ & & & & $\mathrm{x}$ & & & & & \\
\hline Bathyalcyon sp. & $350-360$ & & & & & & & $\mathrm{x}$ & $\mathrm{x}$ & \\
\hline Candidella imbricata (long br, white) & $290-297$ & $\mathrm{x}$ & & & $\mathrm{x}$ & & & & & \\
\hline Unident. octocoral (long br, yellow) & $213-450$ & & & & & $\mathrm{x}$ & & & $\mathrm{x}$ & \\
\hline \multicolumn{11}{|l|}{ Antipatharia } \\
\hline Antipathes sp. & $335-640$ & 4 & 1 & 6 & 3 & 1 & $\mathrm{x}$ & 3 & 3 & 21 \\
\hline Acanthopathes or Phanopathes sp. & $287-427$ & & 3 & & 4 & 2 & 3 & 3 & 8 & 23 \\
\hline Bathypathes sp. & $335-695$ & 1 & 1 & 3 & 5 & $\mathrm{x}$ & 1 & & & 11 \\
\hline ?Stylopathes sp. & $381-701$ & 1 & & & 7 & 2 & & & 4 & 14 \\
\hline Parantipathes cf. tetrasticha & 595 & $\mathrm{x}$ & $\mathrm{x}$ & $\mathrm{x}$ & $\mathrm{x}$ & $\mathrm{x}$ & & $\mathrm{x}$ & $\mathrm{x}$ & \\
\hline ?Tanacetipathes cf. hirta & 573 & $\mathrm{x}$ & & $\mathrm{x}$ & $\mathrm{x}$ & $\mathrm{x}$ & & $\mathrm{x}$ & $\mathrm{x}$ & \\
\hline Tanacetipathes cf. tanacetum & na & & & $\mathrm{x}$ & & & & & & \\
\hline Distichopathes sp. & 274 & & & & & & & $\mathrm{x}$ & & \\
\hline Elatopathes sp. & 366 & & $\mathrm{x}$ & $\mathrm{x}$ & & & & & & \\
\hline Stichopathes cf. pourtalesi & $460-701$ & $\mathrm{x}$ & $\mathrm{x}$ & $\mathrm{x}$ & $\mathrm{x}$ & $\mathrm{x}$ & & $\mathrm{x}$ & $\mathrm{x}$ & \\
\hline Antipathes or Aphanopathes sp. & $381-427$ & $\mathrm{x}$ & & $\mathrm{x}$ & $\mathrm{x}$ & & & $\mathrm{x}$ & $\mathrm{x}$ & \\
\hline \multicolumn{11}{|l|}{ Scleractinia } \\
\hline Dendrophyllia alternata & $366-500$ & $\mathrm{x}$ & & & 4 & 7 & & 1 & 12 & 24 \\
\hline Enallopsammia rostrata & $588-664$ & & 1 & $\mathrm{x}$ & & & & & & 1 \\
\hline Lophelia pertusa & $351-664$ & $\mathrm{x}$ & 1 & & 1 & 1 & & 2 & 2 & 7 \\
\hline Madrepora oculata & $625-628$ & & 1 & & & & & & & 1 \\
\hline Madracis myriaster & $113-165$ & & & & & $\mathrm{x}$ & $\mathrm{x}$ & $\mathrm{x}$ & $\mathrm{x}$ & \\
\hline Madrepora carolina & $150-165$ & & & & $\mathrm{x}$ & $\mathrm{x}$ & $\mathrm{x}$ & & $\mathrm{x}$ & \\
\hline Javania sp. & na & & & $\mathrm{x}$ & & & & & $\mathrm{x}$ & \\
\hline \multicolumn{11}{|l|}{ Crinoidea } \\
\hline Cenocrinus asterius & 140-192 & & & & & & $\mathrm{x}$ & & & \\
\hline Endoxocrinus parrae carolinae & $329-433$ & $\mathrm{x}$ & & & & $\mathrm{x}$ & $\mathrm{x}$ & $\mathrm{x}$ & $\mathrm{x}$ & \\
\hline Crinometra brevipinna & $259-425$ & $\mathrm{x}$ & $\mathrm{x}$ & $?$ & $\mathrm{x}$ & $\mathrm{x}$ & $\mathrm{x}$ & $\mathrm{x}$ & $\mathrm{x}$ & \\
\hline Neocomatella cf. pulchella & $305-420$ & & & & $\mathrm{x}$ & $\mathrm{x}$ & $\mathrm{x}$ & $\mathrm{x}$ & $\mathrm{x}$ & \\
\hline Holopus mikihe & $137-442$ & $\mathrm{x}$ & $\mathrm{x}$ & $\mathrm{x}$ & $\mathrm{x}$ & $\mathrm{x}$ & $\mathrm{x}$ & $\mathrm{x}$ & $\mathrm{x}$ & \\
\hline Cyathidium pourtalesi & $341-427$ & & & & & & & $\mathrm{x}$ & $\mathrm{x}$ & \\
\hline Total (quantified taxa) & & 13 & 20 & 28 & 85 & 62 & 9 & 16 & 72 & 305 \\
\hline
\end{tabular}

Depth ranges are estimated; a single depth is from a sole retrievable record; bold text is the sum total na = unrecorded depth. $L B$, long branch. Abbreviations (see Fig. 1): $A K R$, Anthony's Key; GBB, Gibson Bight; $H M B$, Half Moon Bay; $L B E$, Luna Beach; $L W R$, Lawson's Rock; $O L S$, Old Loafer's; SDM, Sueño del Mar; SDR, Sueño del Bahia 
Fig. 3 Examples of colonial Scleractinia observed during submersible dives. a Madracis myriaster, 122 m, July 15, 2015; b Madrepora carolina, $159 \mathrm{~m}$, July 15, 2015; c Dendrophyllia alternata. $427 \mathrm{~m}, 15$ July 2013; d D. alternata; two color forms: brown in rear and yellow in foreground, same as c; e Desmophyllum pertusum growing outward from under an overhang, 366 m, 4 May 2015
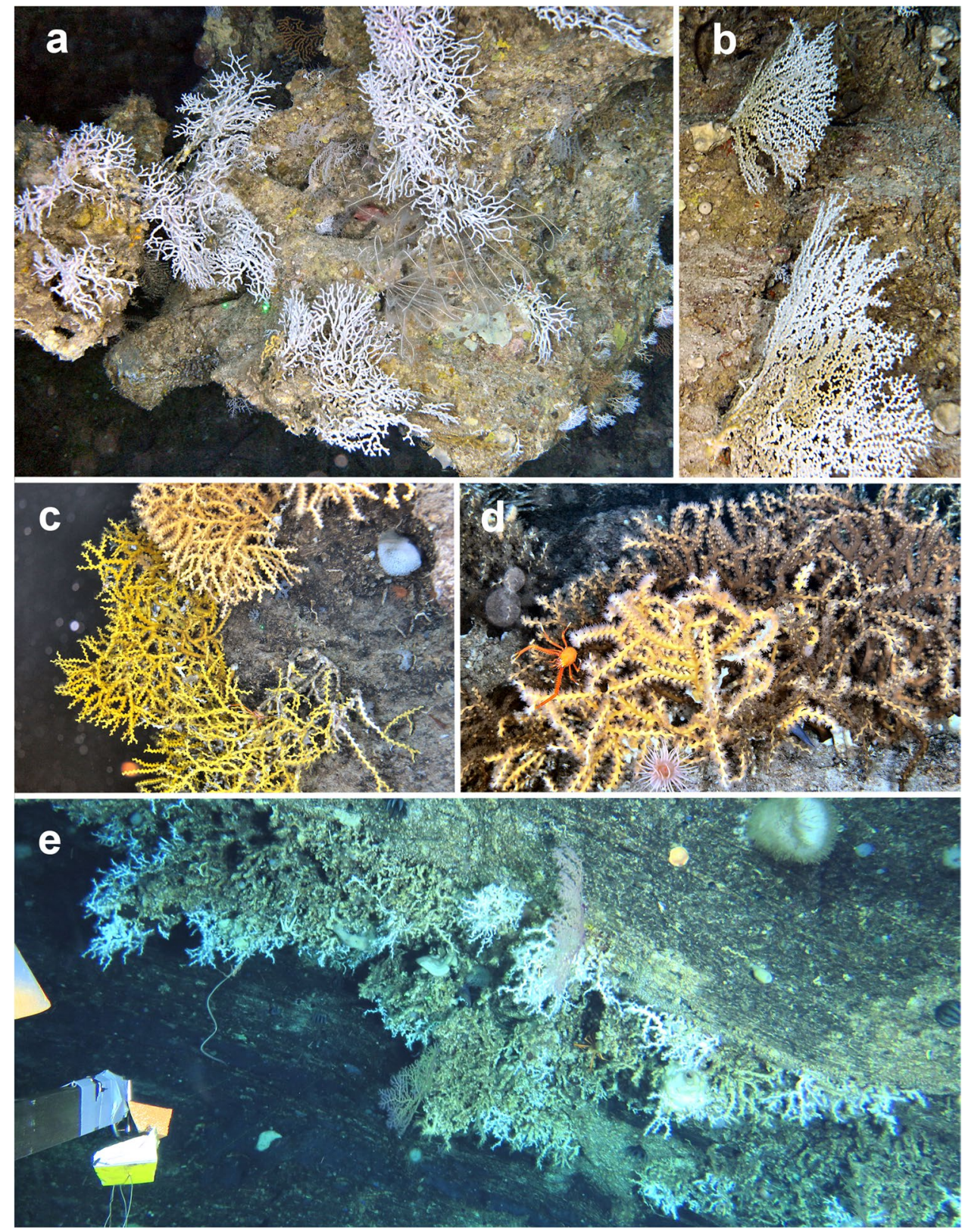

Of other potentially habitat-forming taxa, we observed at least nine crinoid species (Fig. 7). Of these, Cenocrinus asterius (Linnaeus, 1767), the largest and shallowestdwelling stalked crinoid in the western Atlantic, occurred here in an extremely narrow depth range: $\sim 150-155 \mathrm{~m}$ with very few shallower or deeper outliers (140-192 m). Other common crinoid taxa included locally abundant Endoxocrinus parrae carolinae (A.H. Clark, 1934a) (Isselicrinidae), Holopus mikihe Donovan \& Pawson, 2008 (possibly conspecific with $H$. rangii Orbigny, 1837), Cyathidium pourtalesii Améziane et al., 1999 (both Holopodidae), and several feather stars (e.g., Neocomatella pulchella (Pourtalès, 1878) (Comatulidae), Crinometra brevipinna (Pourtalès, 1868) (Charitometridae)). A distinct form of the latter was rarely observed at shallower depths and likely represents a separate species (Fig. 7a). Stalked Democrinus sp. (Rhizocrinidae) was the dominant sessile taxon on sediment slopes (Fig. 7d).

Epifauna observed on all coral groups were predominantly represented by two chyrostyloid anomuran crustaceans (Figs. 3d, 4d,g, 5c, 9b) and Asteroschema laeve (Lyman, 1872) (Euryalidae, Ophiuroidea) (Figs. 4a-c, 8d, $9,10,11$ ), accompanied by fewer numbers of brachyuran crabs, scalpelliform barnacles, feather stars (e.g., N. pulchella) (Figs. 5h, 6b, 7a-b, 8a-b,d, 9b), other ophiuroids (Fig. 5f), the brisingid asteroid Novodinia antillensis (A.H. Clark, 1934b) (Figs. 4g, 11), cidarid echinoids (e.g., Cidaris abyssicola (Agassiz, 1869)) (Fig. 11), actinians, 
Fig. 4 Selected octocorals observed during submersible dives. a Nicella sp. $366 \mathrm{~m}, 11$ June 2012; b Paramuricea sp. (yellow), 427 m, 3 May 2015; c Paramuricea sp. (purple), 402 m, 4 May 2015; d Primnoidae a, Calyptrophorinae, $396 \mathrm{~m}$, 10 June 2012; e Primnoidae b, Narella sp., 640 m, 10 June 2012; f Chrysogorgiidae, depth est. 700 m, 2010; g Hemicorallium niobe, 650 m, May 2011; h Isidella sp., depth 548, 2010; i Isididae, depth 609 m, 2010
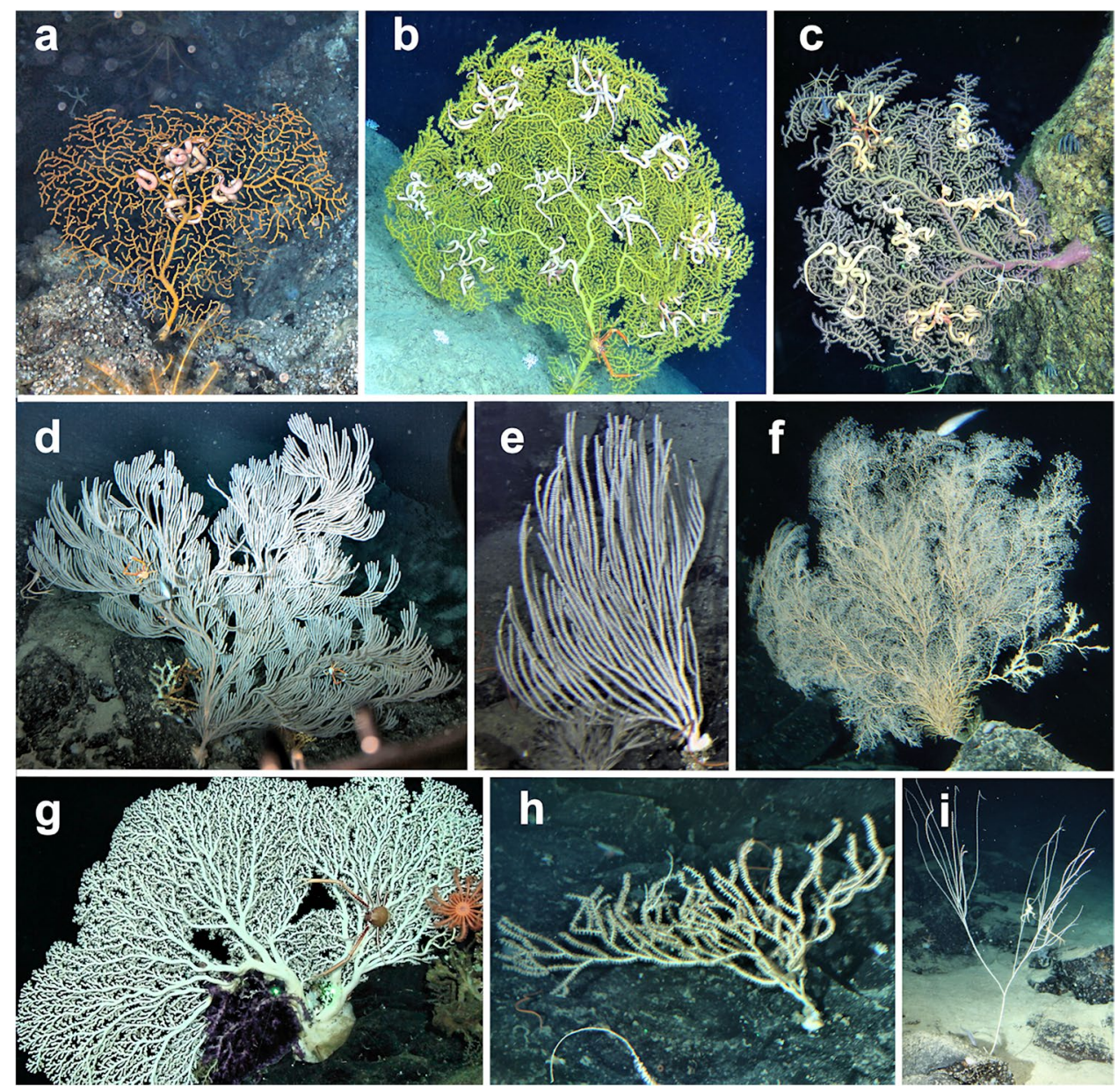

zoantharians (Fig. 8d), and two bythitid fishes. Lavelle (2012) discussed their abundances, distributions, and host preferences.

Few taxa were observed often enough to extract detailed estimates of bathymetric distributions from quantitative dives. However, of the 305 records of the 16 coral morphospecies made during quantitative dives, 201 records of ten species were noted at depths of 335-449 m, followed by 69 records of 13 species in 550-700 m (Table 3, from Lavelle 2012). Of these, seven taxa occurred in both depth zones (i.e., the two Paramuricea morphs, three antipatharians, and Desmophyllum pertusum). Observations in the two other depth ranges included far fewer records: 15 observations of three coral taxa in 150-334 m, and 20 observations of seven taxa in 450-549 m. Three taxa observed at both shallower and greater depths were not recorded in the 450 to 549-m range. In addition, Fig. 8 illustrates how benthic sessile and semi-sessile megafaunal assemblages can exhibit highly restricted distributions and can differ widely over relatively short distances within the same depth range (here only 341-396 m).

The two Paramuricea morphospecies were recorded over strongly overlapping depth ranges, with the purple found in
305-671 $\mathrm{m}(n=78)$ and the yellow in 250-664 $\mathrm{m}(n=81)$. By contrast, members of Primnoidae were chiefly restricted to depths greater than $400 \mathrm{~m}$, whereas Ellisellidae occurred only shallower than this. Large flabellate stylasterid hydrocoral colonies were chiefly observed at depths less than $160 \mathrm{~m}$, with smaller colonies in deeper water. Many taxa were observed only in restricted local habitats within their depth ranges, perhaps associated with specific substrates, topography, and near-bottom hydrodynamic conditions. Desmophyllum pertusum, corallistid sponges, and barnaclelike cyrtocrinid crinoids $H$. mikihe and $C$. pourtalesii were observed chiefly on vertical or near-vertical surfaces, versus Paramuricea spp. typically on projecting rocky substrates or where high-relief topography may be focusing near-bottom flow.

\section{Observations of corallivory and epibionts}

With respect to predation, the echinoid Cidaris abyssicola was observed climbing, and ostensibly feeding on, Paramuricea sp. (yellow) (see below), Enallopsammia rostrata, and Bathypathes sp. The pleurotomariid slit snail Bayerotrochus midas (Bayer, 1966) was documented on a glass 
Fig. 5 Selected antipatharians observed during submersible dives (see Table 1). a Antipathes sp., 366 m, 11 June 2012; b Phanopathes sp. or Acanthopathes sp., depth $326 \mathrm{~m}$, 17 July 2013; c Stylopathes sp., depth est. 460-560 m, 22 May 2011; d Bathypathes sp., depth $609 \mathrm{~m}$, off Gibson Bight, 02 Dec 2011; e Stichopathes $\mathrm{cf}$. pourtalesii (unbranched orange corkscrews) and Parantipathes cf. tetrasticha (bottlebrush), $595 \mathrm{~m}, 10$ June 2012; f Antipathes sp. or Pteropathes sp. with asteroschematid ophiuroids, $427 \mathrm{~m}$, 10 June 2012; g Tanacetipathes cf. hirta, 430-450 m, off Lawson's Rock, 26 May 2011; h Elatopathes sp., $366 \mathrm{~m}$, 10 June 2012; i Antipathes or Aphanopathes sp., $442 \mathrm{~m}, 16$ July 2013
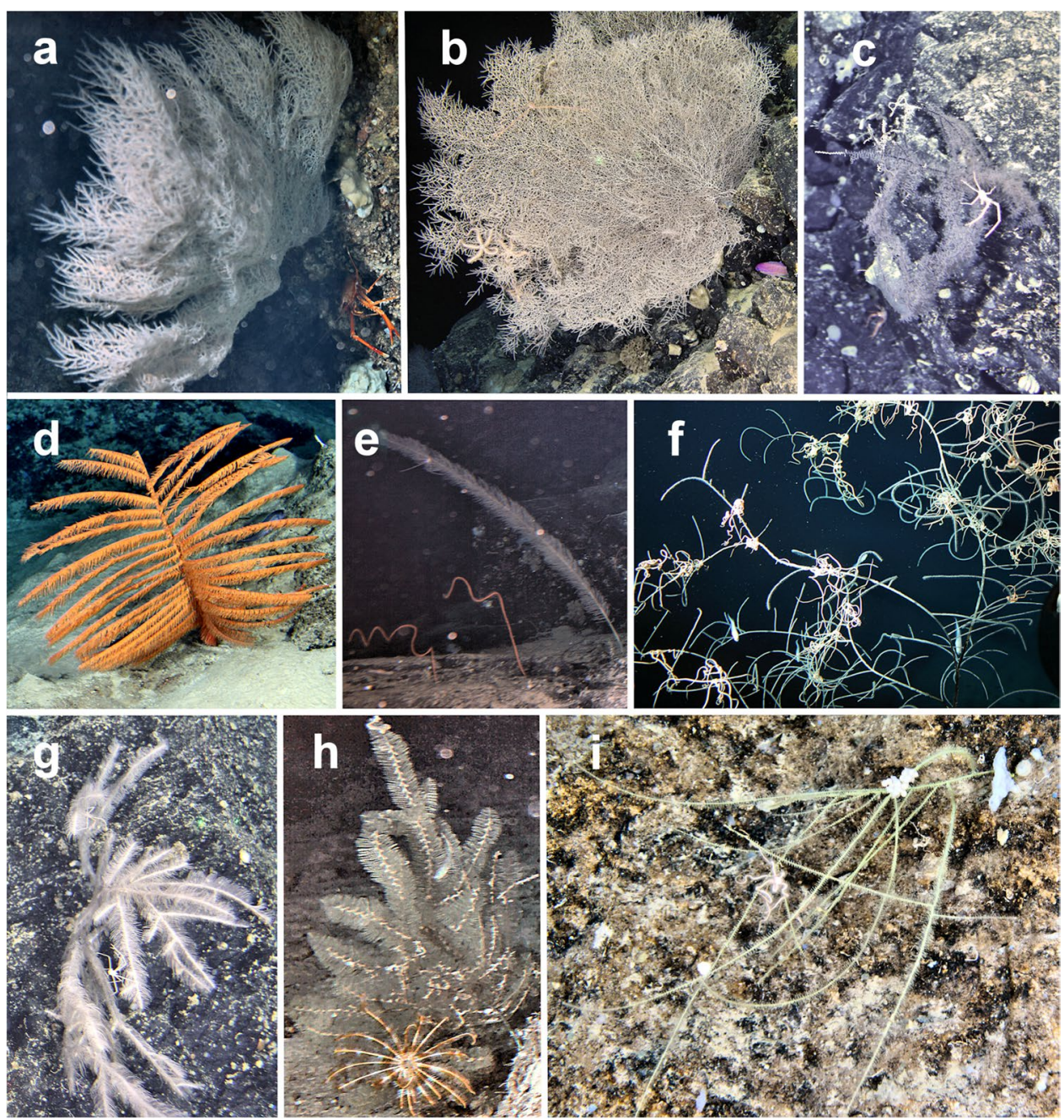

sponge and climbing a partly denuded colony of Chrysogorgiidae. Although this might reflect feeding behavior, its family, Pleurotomaridae, has not been reported as feeding on corals (M. G. Harasewych, Smithsonian NMNH, pers. comm.). Four species of slit snails were collected: B. midas, Entemnotrochus adansonianus (Crosse \& Fischer, 1861), Perotrochus quoyanus (Fischer \& Bernardi, 1856), and P. cf. charlestonensis Askew, 1988 (Etnoyer et al. 2011). Several relatively denuded Paramuricea sp. colonies were also observed (Fig. 9) but with no potential predators visible.

Repeated observations of a few octocoral colonies revealed variations in predation, recolonization, and epibiont host fidelity. Figure 10 shows a Paramuricea sp. that suffered no obvious predation over at least a 9-year period (2010-2019), whereas Fig. 11 shows a different colony that illustrates a multiyear decline, including branch loss, denuded skeleton, regeneration of polyps, and subsequent regrazing of polyps.

The pencil urchin Cidaris abyssicola was observed on the colony in 2008 and again later, adjacent to its base in
2013 (Fig. 11). Evidence of predation was present already, in the form of denuded branches, before the urchin was first observed on the colony. Cidarid pencil urchins appear to be among the most likely corallivores in this ecosystem. The urchins were observed upon colonies of Dendrophyllia alternata and Bathypathes sp., but these colonies showed no evidence of injury.

Figure 11 also shows the movement and eventual loss of two Asteroschema laeve brittle stars on this Paramuricea colony over a 14-year period. In 2006, one clung on the left- and one on the right-hand branch. They exhibited evidence of predation on the tips of their arms where the brittle stars appeared to be regenerating new, smaller arm segments. In 2008, two were on the left-hand branch, also with regenerating arm tips. In 2010, only one remained but with polyp regrowth on the coral colony by 2012; a second had returned on the right-hand branch and remained through 2013. With substantial polyp loss by 2014, both ophiuroids had vacated. However, in an image taken later in 2014 (not shown), the small clusters of polyps on the far right-hand branch (upper, middle, and lower) had all 
Fig. 6 Selected sponges observed during submersible dives. a-j Hexactinellida; k-o Demospongiae. a Iphiteon panicea, 274-290 m, 15 July 2012; b Dactylocalyx pumiceus, $370 \mathrm{~m}, 10$ June 2012; c ?Vazella pourtalesiii, $\sim 360 \mathrm{~m}$, 10 June 2012; d Sympagella sp, 137 m, 5 May 2015; e Euplectellidae, Corbitellinae sp. A 575-590 m, Luna Beach, 22 May 2011; f Euplectellidae, Corbitellinae sp. B ?365 m, Anthony's Key/Three Kings, 25 May 2011; g Farrea sp. A depth est. 500 m, Gibson Bight, Dec 2011; h Farrea sp., 424 m, 3 May 2014 (reoriented vertically); i Dactylocalycidae. 137 m, 5 May 2014; j Hexasterophora inset, $293 \mathrm{~m}, 3$ May 2015; k Corallistidae, $\sim 433 \mathrm{~m}, 5$ May 2015; l Leiodermatium sp. 488 m, Gibson Bight, Dec 2011; m Spongosorites sp., 326 m, 17 July 2013; n Tetractinellida, 370 m, 10 June 2012; o Unidentified barrel demosponge with small blue encrusting Desmacellidae, $320 \mathrm{~m}$, 11 June 2012. $\mathbf{i}$ and $\mathbf{j}$ were recorded only during nonquantitative crinoid dives
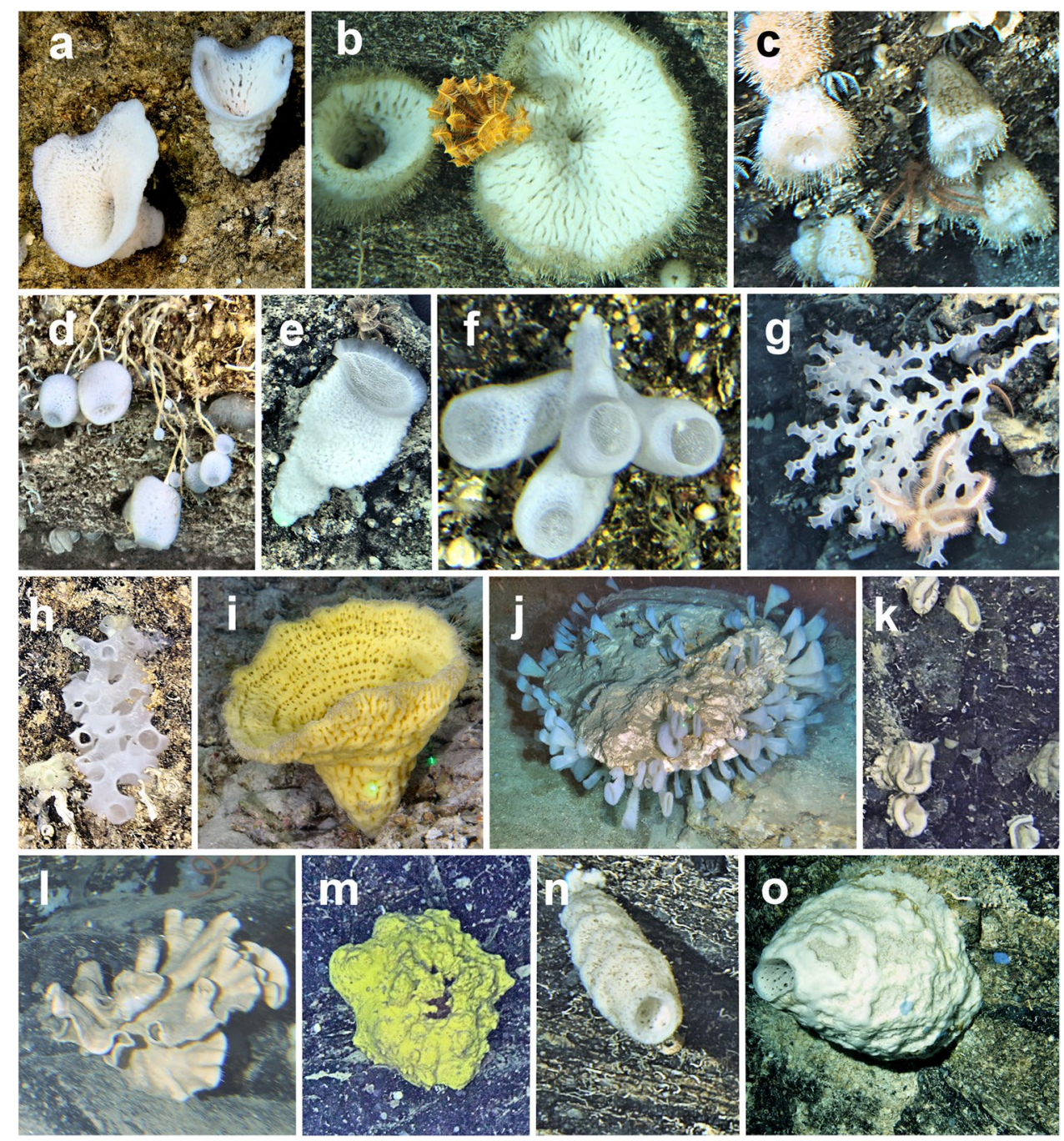

disappeared, and two A. laeve had reappeared, one on the right-hand branch and a smaller one among the remaining living polyps on the upper left-hand branch. In 2015, a small A. laeve on the right-hand branch was the only one present. None were present in images taken in 2019 or 2020.

For other epibionts on the same colony, a small scalpelliform barnacle was first visible in 2010 and remained through 2013 (Fig. 11; on the left-pointing branch of the right-hand branch cluster, although possibly obscured by $N$. antillensis in 2008 and 2009) before disappearing with substantial polyp loss by 2014 . Mobile crustaceans included Rochinia hystrix (Stimpson, 1871) in 2006 and 2012 and a smaller one in 2014 (not shown), and a chirostylid anomuran in 2019 and 2020. Taken together, these repeated observations show a decade-long demise of an injured sea fan under natural pressures, with subsequent abandonment of associated epibionts.

\section{Discussion}

The observations presented here contribute to a growing body of literature using human-occupied vehicles (HOVs or submersibles) to explore the Caribbean deep sea and to study the benthic ecology of the Mesoamerican Reef (MAR), in particular, which is the second-longest fringing barrier reef in the world. Scientific expeditions of the MAR since the 1900's deployed trawls and dredges from the US Fisheries Commission steamers Blake and Albatross and from the University of Miami's R/V Pillsbury in the 1960s. These expeditions provided tissue samples from the deep-sea floor that are now well illustrated in books and reside preserved in national archives.

What is different about the submersible-based research is that we are seeing these animals alive for the first time, observing their behavior and tracking their survival over time using images. This is being done in a selective and targeted manner, 
Fig. 7 Selected Crinoidea observed during submersible the steep forereef slope with a Crinometra sp. (shallow form) (lower-left), 150 m, 7 July 2014. C. asterius arm length 12-14 cm; b Eight short-stalked Endoxocrinus parrae carolinae with two orange Neocomatella pulchella (upper left) and four yellow Crinometra brevipinna (both feather stars) on a hexactinellid sponge, $366 \mathrm{~m}, 4$ May 2014. E. parrae arm length 14-17 cm; c Three Holopus cf. mikihe, with tiny juvenile and small black Cyathidium pourtalesii (both lower-left), on a vertical wall, $421 \mathrm{~m}$, May 2015. Distance between cups of the top two Holopus cf. mikihe $10 \mathrm{~cm}$; d Democrinus sp. on a sediment slope, $223 \mathrm{~m}$, 11 June 2012. Democrinus sp. arm length $\sim 6 \mathrm{~cm}$ dives. a Cenocrinus asterius on
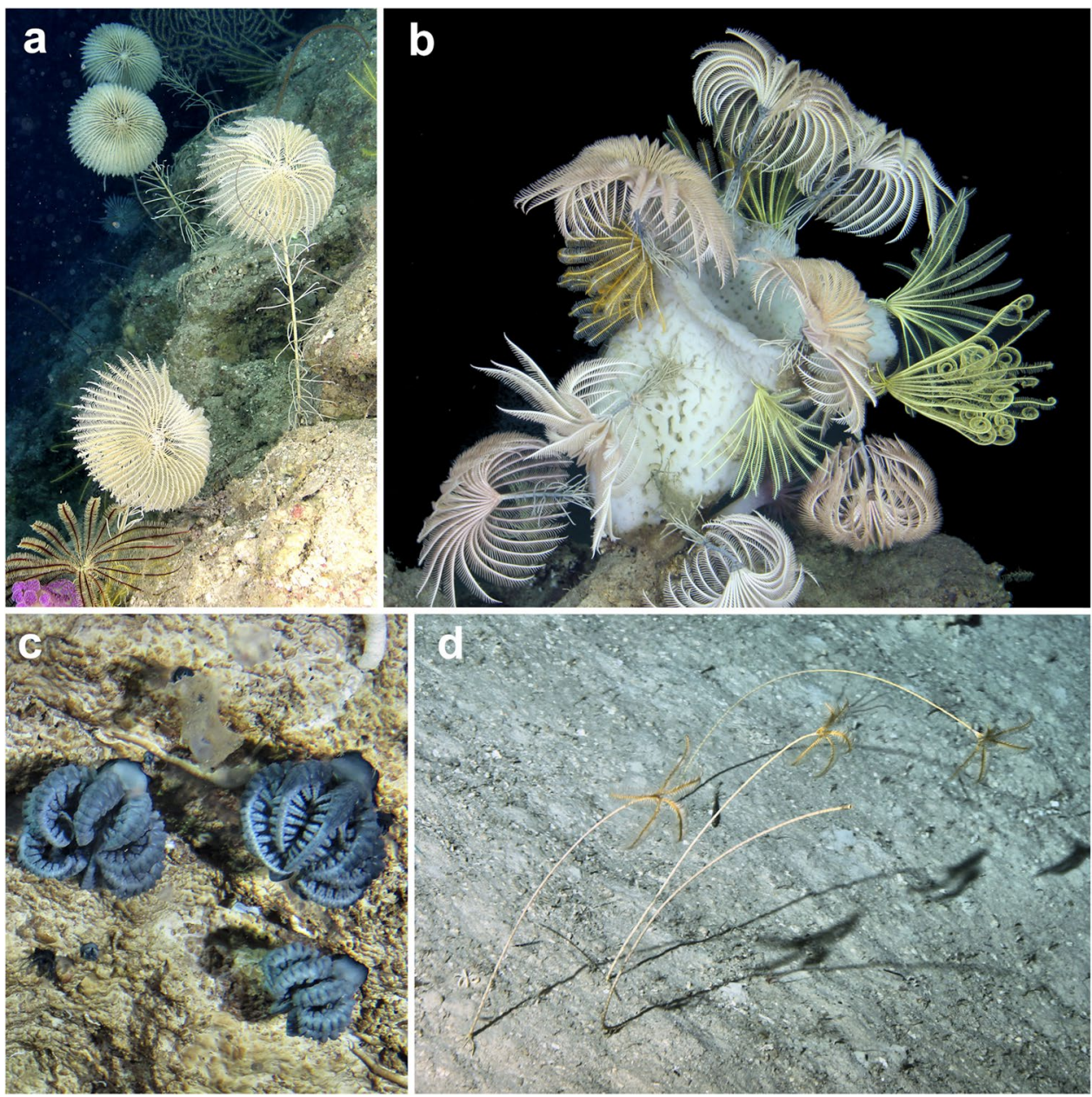

Fig. 8 Local variation in benthic sessile and semisessile megafauna within a narrow depth range (341-396 m). a Desmophyllum pertusum on an overhanging ledge, $365 \mathrm{~m}$; b Endoxocrinus parrae carolinae, Crinometra brevipinna, and hexactinellid sponges, $341 \mathrm{~m}$. E. parrae arm length 14-17 cm; c Dendrophyllia alternata, 396 m; d Paramuricea spp., zoantharians, feather stars, and Asteroschema laeve, 347 m
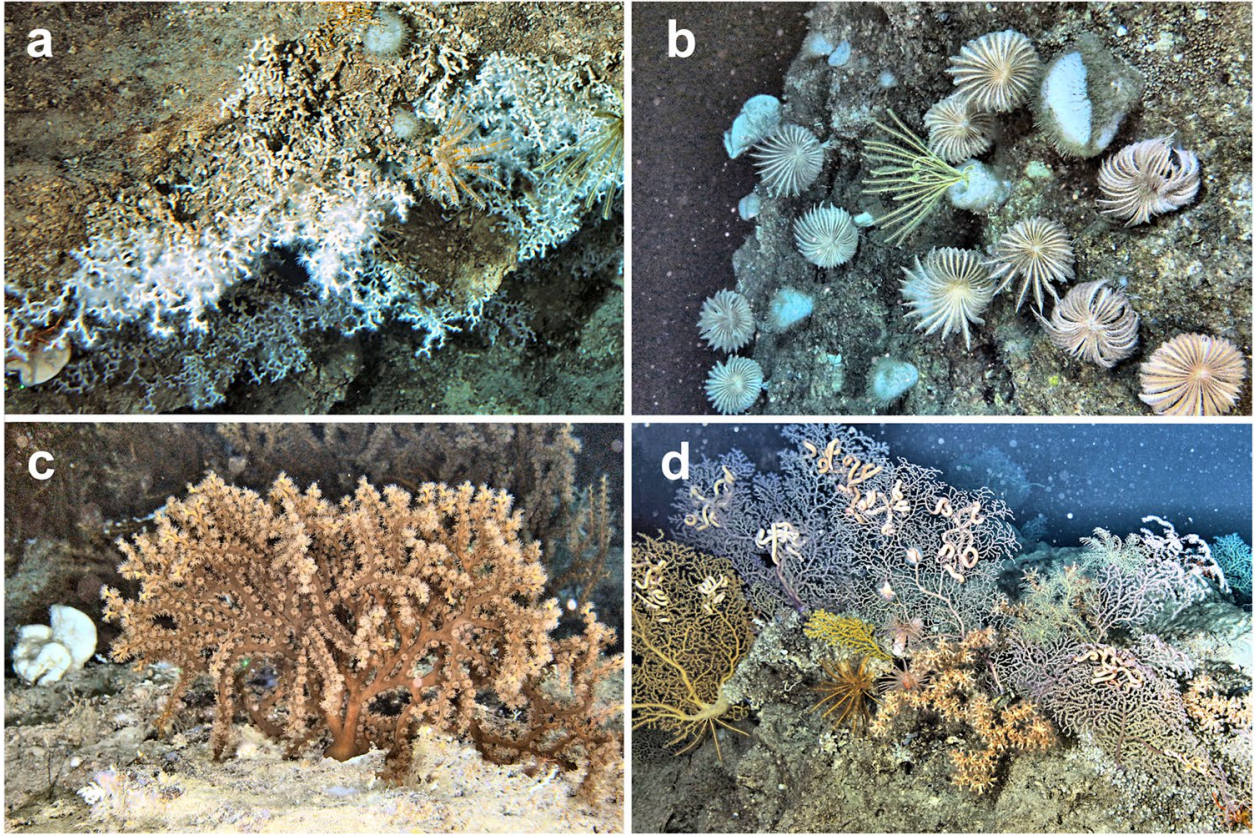


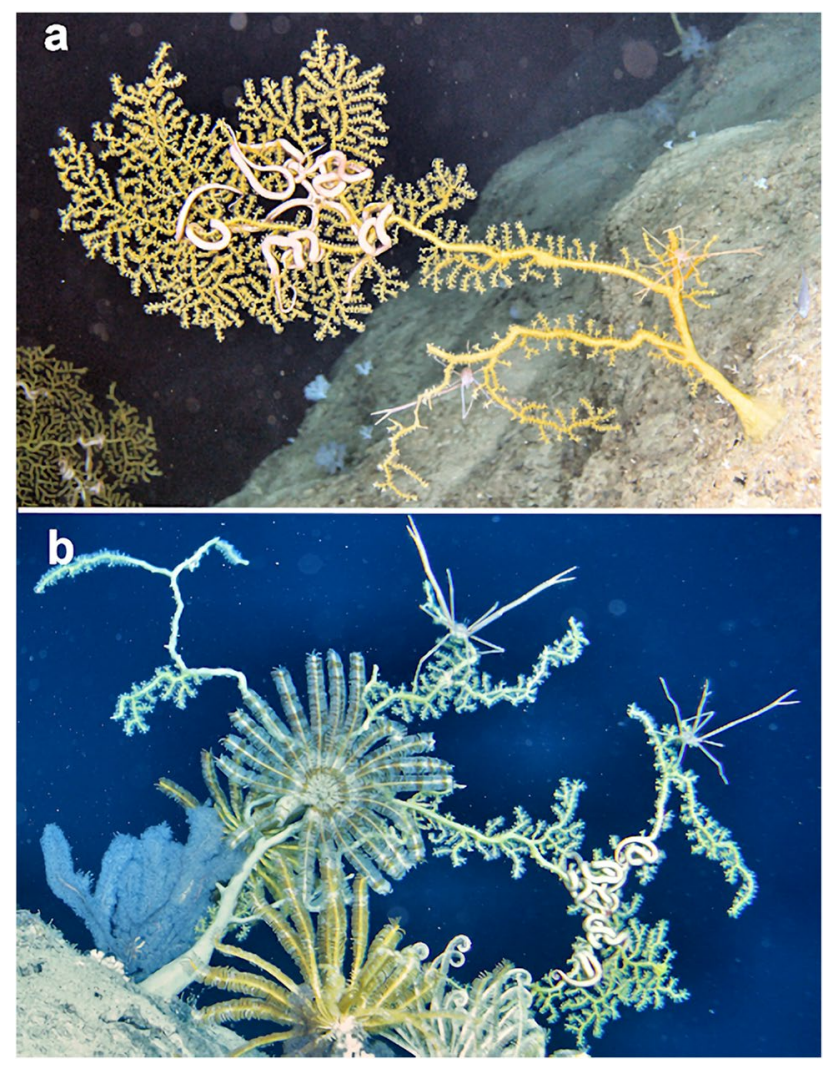

Fig. 9 Partially preyed-upon Paramuricea sp. (yellow); no predators present. a With Asteroschema laeve and two chyrostyloid squat lobsters, 402-421 m, 14 July 2013; b With Asteroschema laeve, Neocomatella pulchella (feather star at center), and two chyrostyloid squat lobsters. Other organisms are an unidentified antipatharian (left) and two Crinometra brevipinna (feather stars, foreground), depth between 500 and 700 m, 23 May 2011. C. brevipinna arm length 20-25 cm

with negligible impact on the benthic community. The submersible can access a steep rocky habitat that is common in the 150-800 $\mathrm{m}$ depth range throughout the western Caribbean (James and Ginsburg 1979). The steep grade is relatively inaccessible to other types of sampling gear like trawls and dredges and is actually very difficult to map with precision.

The collaborative nature of the 10-year study was also somewhat unique. Over time, we attracted assets like the Research Vessel Falkor to map Roatan's seafloor using multibeam echo sounders (NOAA 2013), and experts in taxonomy from NMNH to identify invertebrate predators. We were able to collect seafloor images, water chemistry data, bathymetry data, and tissue samples of corals, gastropods, and crinoids. We did not attempt to collect sediments or tissue samples of fishes or soft corals. This would require a multifunction manipulator, as well as the funds and time to do so. There is considerably more sampling work to be done.

Images of species in their natural habitat do not provide DNA, but they can provide details of morphology often (usually) destroyed by trawling or dredging. Photographs and video observations are collected along a swath that documents spatial relationships among species and assemblages, with relatively high precision. The images also provide evidence of the orientation of individuals in situ with regard to their habitat, currents, and other species. Trawls, dredges, and grabs do not permit time-series analyses of the same individual specimens to record age, predation, recovery and regrowth, or the fate of their epibionts. These latter methods do allow sampling and systematic assessments over very large areas (e.g., Santodomingo et al. 2013).

The Mesoamerican Reef has been explored using submersibles since the 1970s but rarely as deep as the observations shown here. The Nekton submersible explored the geology of the MAR to $300 \mathrm{~m}$ using film cameras (James and Ginsburg 1979). Since 1990, no less than 100 submersible dives have taken place between Cozumel and Curacao (NOAA 2019). Johnson Sea Link I submersible (JSL I) made 32 dives to survey along the Yucatan Peninsula from Cozumel to Belize, working to a maximum depth near $365 \mathrm{~m}$ in 1990. The JSL II submersible made another 30 dives to a depth of $600 \mathrm{~m}$ in 1997. Together, these dives represent a 50-year body of submersible exploration spanning $>1000 \mathrm{~km}$.

However, data on diversity and abundance of sessile benthic megafauna deeper than $300 \mathrm{~m}$ are relatively new to scientific discourse in the western Caribbean. A 10-year series of epibenthic trawl surveys sponsored by Marine and Coastal Research Institute (INVEMAR) off the Columbian Caribbean coast explored depths from 20 down to $500 \mathrm{~m}$. A total of 142 species of azooxanthellate corals was collected and archived through the research, and those deeper than $200 \mathrm{~m}$ were found to be relatively widespread (Santodomingo et al. 2013).

The present study begins with DeepCAST in the year 2010 and dives to depths between $150-750 \mathrm{~m}$ to find relatively few taxa in high abundance and document them alive in their habitat over time and in detail. This depth range is deeper than most submersible surveys in the Caribbean Sea but nearly equivalent to JSL II dives from Curacao in May of 2000. A similarly inspired effort called Deep Reef Observing Program (DROP) began coincidentally in the Dutch Antilles in 2010, at nearly the same time as the present study, working to a depth of $300 \mathrm{~m}$. The DROP documented many new species of fishes, including blennies, sea bass, and gobies (Baldwin and Robertson 2013, 2014; Tornabene et al. 2016), as well as cusk eels, octopods (Pratt et al. 2019), and hermit crabs (Lemaitre et al. 2017). These descriptions and observations are documented in no less than two dozen papers.

We used the Idabel sub to illustrate the diversity of the benthic assemblages off Isla de Roatán at a coarse taxonomic level, in an effort to highlight the importance of structureforming corals for mobile invertebrates in the deep sea and offer insights into the stability and variability of benthic megafaunal assemblages on a Caribbean deep island slope 
Fig. 10 Paramuricea sp. (yellow) in $384 \mathrm{~m}$ showing no obvious predation or growth over a 9-year span. (The original higher-resolution version of the 2010 image cannot be located.) Numbers of epibiont Asteroschema laeve remain the same, at least from 2014 to 2016 but with some relocation. Differences in apparent branch thickness between earlier images and 2019 are likely associated with polyp expansion versus contraction

over an extended time span. Image data allowed us to document the diversity, distribution, and abundance of key species. Repeat observations allowed us to monitor growth and behavior, and characterize species distributions.

The topography of the deep island slope off West End, Roatán, is quite variable and in many places highly complex, rugged, and incised by a series of sedimentary channels. Although the location of these sites along the western island slope protects them from strong flow associated with the northwestward flowing Caribbean Current (Richardson 2005), there appears to be enough productivity and near-bottom flow to maintain diverse and often dense assemblages of suspension-feeding megafauna. Orientation of fan-shaped stony coral, octocoral, and black coral colonies reflect longterm responses to near-bottom flow conditions, both acrossslope (e.g., Figs. 3b, 4a-g, and 5a-d) and upslope (Fig. 6h). The latter and other images (not shown) of horizontally oriented, concave-downslope coral colonies suggest the existence of localized upwelling. Also, the highly localized and in many cases restricted distributions of many taxa likely reflect important small-scale variations in near-bottom flow and food availability.

Observations of several Paramuricea sp. colonies over time reveal variations in predation ranging from no obvious predation (Fig. 10) to virtually complete colony death (Fig. 11). These observations are important because they provide evidence of a long, slow decline in deep-sea coral colonies in the absence of known anthropogenic impacts such as fishing gear entanglement or oil spills. The partial regeneration of one of the octocorals suggests that recovery is possible, but it can be negatively affected by grazing. Injured sea fans in the Gulf of Mexico also showed limited ability to regenerate after Deepwater Horizon (Fisher et al. 2014; Etnoyer et al. 2016; Girard and Fisher 2018). However, Girard et al. (2016) described a mutualistic symbiosis in which brittle stars Asteroschema clavigerum Verrill, 1894, on Paramuricea biscaya Grasshoff, 1977, benefitted the octocoral colonies following the oil spill, likely via the ophiuroids removing material deposited on the polyps and possibly by inhibiting settlement of hydroids.

A similar mutualist relationship was described between the snake star Astrobrachion constrictum (Farquhar) and the black coral Antipathes fiordensis in Doubtful Sound, New Zealand (Stewart 1998). One method of feeding by the euryalid brittle star was for its arms to wipe across the branches of the host coral colony, gathering plankters and
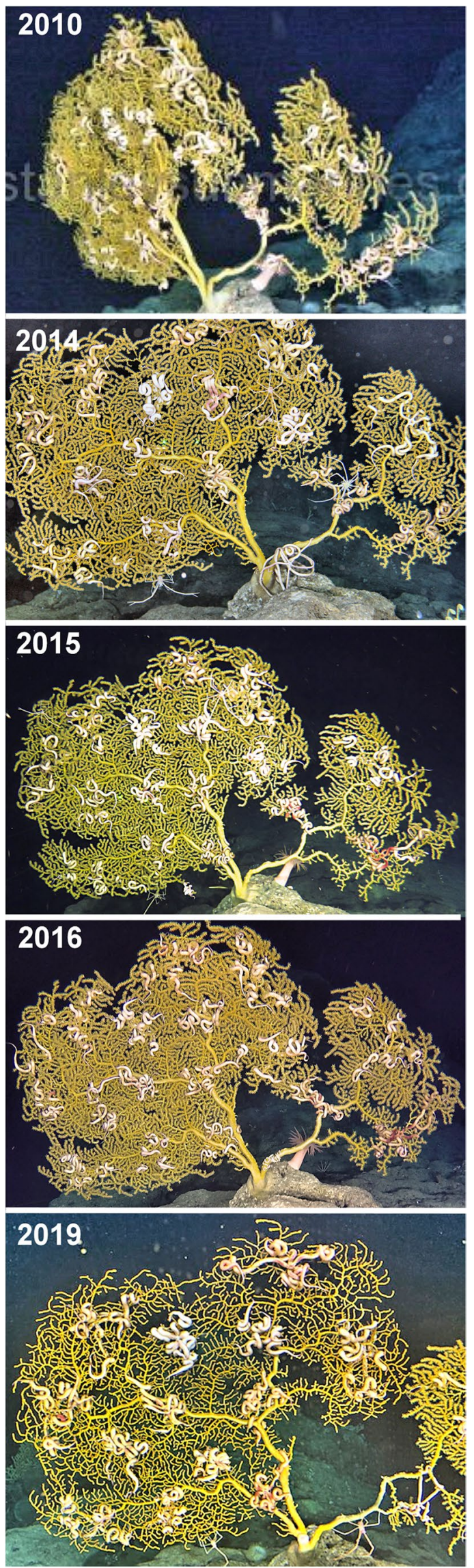
Fig. 11 Paramuricea sp. (yellow), time series of the decline, partial regrowth, and eventual almost complete demise of a colony in $408 \mathrm{~m}$ over a 14-year time span. Note polyp regrowth on the right-hand branch in 2010 , with accelerated regrowth in 2012 and 2013, followed by substantial polyp loss in 2014 through 2015, and colony breakage and almost complete denudation by 2019. A small branch with live polyps remains (bottom-left) in 2020. Variations in the location and presence/absence of Asteroschema laeve and other commensals are treated in the text. The large orange sea star is the suspension-feeding Novodinia antillensis

Table 3 Distribution of identified coral species counted during quantitative dives by depth zone (from Lavelle 2012)
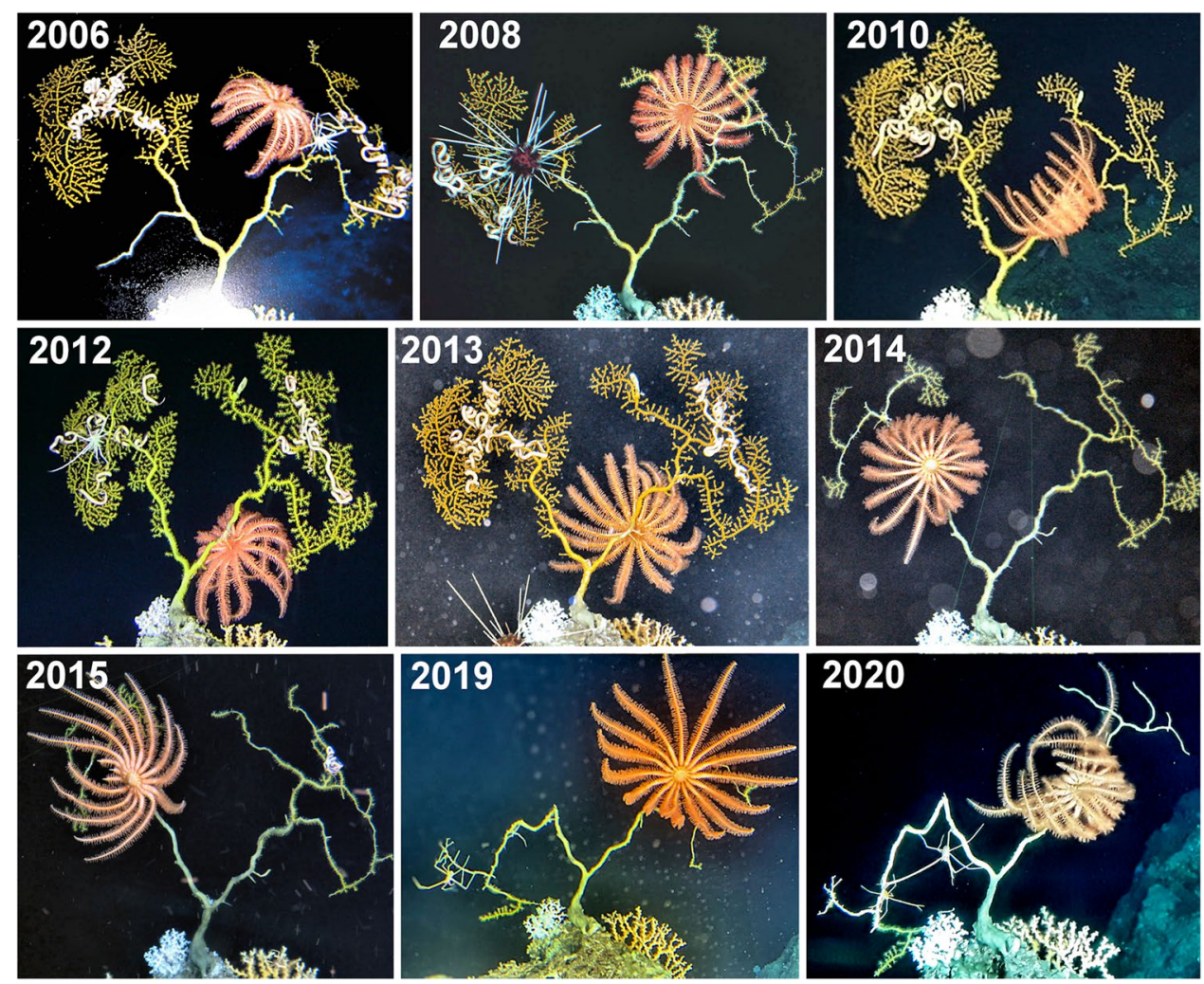

\begin{tabular}{|c|c|c|c|c|c|}
\hline \multirow[t]{2}{*}{ Species } & \multicolumn{4}{|c|}{ Depth zone $(\mathrm{m})$} & \multirow[b]{2}{*}{ Tota } \\
\hline & $150-334$ & $335-449$ & $450-549$ & $550-700$ & \\
\hline \multicolumn{6}{|l|}{ Octocorallia } \\
\hline Acanthogorgia sp. & & & & 1 & 1 \\
\hline Chrysogorgiidae sp. & & & & 3 & 3 \\
\hline Corallium niobe & & & 1 & 5 & 6 \\
\hline Lepidisis sp. & & 1 & 1 & & 2 \\
\hline Paramuricea sp. (purple) & 1 & 75 & & 2 & 78 \\
\hline Paramuricea sp. (yellow) & 7 & 67 & 4 & 3 & 81 \\
\hline Primnoidae sp. A (Calyptrophorinae) & & 1 & 7 & 19 & 27 \\
\hline Primnoidae sp. B (Narella sp.) & & & & 5 & 5 \\
\hline \multicolumn{6}{|l|}{ Antipatharia } \\
\hline Antipathes sp. & & 5 & 3 & 13 & 21 \\
\hline Acanthopathes or Phanopathes sp. & 7 & 16 & & & 23 \\
\hline Bathypathes sp. & & 1 & & 10 & 11 \\
\hline Plumapathes sp. & & 11 & 1 & 2 & 14 \\
\hline \multicolumn{6}{|l|}{ Scleractinia } \\
\hline Dendrophyllia alternata & & 21 & 3 & & 24 \\
\hline Enallopsammia rostrata & & & & 1 & 1 \\
\hline Lophelia pertusa & & 3 & & 4 & 7 \\
\hline Madrepora oculata & & & & 1 & 1 \\
\hline Total & 15 & 201 & 20 & 69 & 305 \\
\hline
\end{tabular}

Bold text is a sum total 
detritus along with mucus from the coral polyps. The coral polyps were not harmed. The snake stars apparently assisted in keeping the host coral colony free from epizoic organisms and from detritus which otherwise may have smothered the colony or impeded feeding. In contrast, our study suggests that epibionts such as Asteroschema laeve, Novodinia antillensis, feather stars (e.g., Neocomatella puchella and Crinometra brevipinna), and chyrostyloid squat lobsters ultimately confer no protection to Paramuricea sp. colonies over the long term, at least to megafaunal predation (Grange 1991; Stewart 1998).

Cidarid pencil urchins are considered here to be among the most likely predators on these colonies off Roatán. However, in more temperate waters of the North Pacific and North Atlantic, asteroids are more commonly observed feeding on deep-sea corals (Mah et al. 2010). Asteroids similar to Hippasteria were observed on several of our dives but cannot be identified from our photographs and video images (C. Mah, Smithsonian NMNH, pers. comm.).

The diets of deep-sea regular echinoids are poorly studied, but they are presumably broad generalists and carnivores on sluggish or sessile organisms (Jangoux and Lawrence 1982), including predation by cidarids on stalked crinoids (Baumiller et al. 2008). The shallow-water echinoid Arbacia lixula (Linnaeus, 1758), a dominant sea urchin in the Mediterranean, was long considered to be an herbivore but later found via stable isotope analysis to be omnivores tending to carnivory and feeding on a wide variety of invertebrate taxa, including hydrozoans (Wangensteen et al. 2011). Although we have only video observations of the echinoid Cidaris abyssicola ostensibly feeding on a variety of invertebrate taxa, the frequency of these observations over time, suggests that it may be a predator of some deep-sea corals, particularly yellow Paramuricea sp. We hypothesize that Cidaris abyssicola might use a homing strategy perhaps similar to that of the sea urchin Diadema antillarum Philippi, 1845, in shallow water, in which the urchins avoid repeatedly feeding on exactly the same areas of the seafloor (Carpenter 1984).

Future scientific studies should conduct sampling to verify and improve the taxonomic resolution reported here and investigate the predator-prey field for deep-sea corals in disturbed ecosystems, such as the Gulf of Mexico and more natural ecosystems, like the Bay Islands of Honduras. Our study illustrates the precision and utility of submersibles for repeat observations over long time frames. Given the scientific and economic value of these platforms, we advocate for their broader use, particularly where the deep sea is readily accessible from shore.

Acknowledgements Thanks to the reviewers for their improvements to this manuscript and to the subject matter experts who contributed to the manuscript revision. The authors wish to acknowledge the following sponsored projects that contributed data to this research: (1) "DeepCAST I (Deep Coral and Associated Species Taxonomy \& Ecology)
Expedition," 13-18 August 2010, Texas A\&M University-Corpus Christi (TAMUCC), Harte Research Institute (T. Shirley, P.I.) and Marine Science \& Technology Foundation (MSTF), Schmidt Ocean Institute (SOI) (P. Etnoyer, P.I.); (2) "DeepCAST II Expedition,” 21-28 May 2011, National Oceanic and Atmospheric Administration (NOAA) (P. Etnoyer, P.I. (MOA-2011-059/8341); (3) "DeepCAST III Expedition," 27 Nov-3 Dec 2011, Faculty Research Grant, TAMUCC (T. Shirley, P.I.), and MSTF/SOI (P. Etnoyer, P.I.); (4) "Ecology of the "Living Fossil" Holopus rangii (Echinodermata: Crinoidea)," President's Faculty Research and Development Grant, Nova Southeastern University (C.G. Messing, P.I.); (5) "Predation and its effects on the bathymetric distribution of crinoids," National Geographic Society, 2015 (T. K. Baumiller, P.I.). Data and photographs from DeepCAST I, II, and III were used by K. Lavelle in her M.S. thesis at TAMUCC and by T. Shirley and P. Etnoyer on other projects. Data and photographs from the NSU and National Geographic grants have contributed to other projects and publications by C.G. Messing and T.K. Baumiller. We also wish to thank the following individuals for their taxonomic expertise and assistance in identifying invertebrates from photographs taken during these projects: fishes - Dr. Steve Ross (University of North Carolina-Wilmington). Octocorallia - Dr. Steven Cairns (Smithsonian Institution). Antipatharia - Dennis Opresko (Smithsonian Institution); Porifera - Henry Reiswig (Dept. of Biology, University of Victoria, and Natural History Section, Royal British Columbia Museum, Victoria, British Columbia, Canada), John K. Reed and Maria Cristina Diaz (Harbor Branch Oceanographic Institute, Florida Atlantic University, Fort Pierce, FL, USA), Cristiana Castello Branco (Museu Nacional/ Universidade Federal do Rio de Janeiro, Brazil), and Allen Collins (Smithsonian Institution).

\section{Declarations}

Conflict of interest The authors declare no competing interests.

Ethics approval No animal testing was performed during this study.

Sampling and field studies All necessary permits for sampling and observational field studies have been obtained by the authors from the competent authorities and are mentioned in the Materials and methods section, if applicable. The study is compliant with CBD and Nagoya protocols.

Data availability The datasets generated during and/or analyzed during the current study are available from the corresponding author upon reasonable request.

Author contribution PE and TS conceived and designed the primary research project. $\mathrm{CM}$ and $\mathrm{TB}$ contributed data from separate research projects. PE, TS, TB, and CM acquired funding. All authors assisted in data collection and logistics. KS piloted the sub, assisted with site selection, and provided image data. KL, TS, TB, and CM analyzed data. CM, PJE, and TS wrote the manuscript. All authors read and approved the manuscript.

Open Access This article is licensed under a Creative Commons Attribution 4.0 International License, which permits use, sharing, adaptation, distribution and reproduction in any medium or format, as long as you give appropriate credit to the original author(s) and the source, provide a link to the Creative Commons licence, and indicate if changes were made. The images or other third party material in this article are included in the article's Creative Commons licence, unless indicated otherwise in a credit line to the material. If material is not included in the article's Creative Commons licence and your intended use is not permitted by statutory regulation or exceeds the permitted use, you will 
need to obtain permission directly from the copyright holder. To view a copy of this licence, visit http://creativecommons.org/licenses/by/4.0/.

\section{References}

Addamo AM, Vertino A, Stolarski J, García-Jiménez R, Taviani M, Machordom A (2016) Merging scleractinian genera: the overwhelming genetic similarity between solitary Desmophyllum and colonial Lophelia. BMC Evol Biol 16(1). https://doi.org/10.1186/ s12862-016-0654-8

Agassiz A (1869) Preliminary report on the echini and star-fishes dredged in deep water between Cuba and the Florida Reef, by L. F. de Pourtalès, Assist. U.S. Coast Survey. Bull Mus Comp Zool 1(9):253-308

Améziane N, Bourseau J-P, Heinzeller T, Roux M (1999) Les genres Cyathidium et Holopus au sein des Cyrtocrinida (Crinoidea; Echinodermata). J Nat Hist 33:439-470

Askew TM (1988) A new species of pleurotomariid gastropod from the western Atlantic. The Nautilus (Philadelphia, PA) 102(3):89-91

Baumiller TK, Mooi R, Messing CG (2008) Urchins in the meadow: paleobiological and evolutionary implications of cidaroid predation on crinoids. Paleobiol 34(1):35-47. https://doi.org/10.1666/ 07031.1

Baldwin CC, Robertson DR (2013) A new Haptoclinus blenny (Teleostei, Labrisomidae) from deep reefs off Curacao, southern Caribbean, with comments on relationships of the genus. ZooKeys 306:71-81. https://doi.org/10.3897/zookeys.306.5198

Baldwin CC, Robertson DR (2014) A new Liopropoma sea bass (Serranidae: Epinephelinae: Liopropomini) from deep reefs off Curaçao, southern Caribbean, with comments on depth distributions of western Atlantic liopropomins. ZooKeys 409:71-92. https://doi. org/10.3897/zookeys.409.7249

Bayer FM (1964) The genus Corallium (Gorgonacea: Scleraxonia) in the Western North Atlantic Ocean. Bull Mar Sci Gulf Carib 14(3):465-478

Bayer FM (1966) New pleurotomariid gastropods from the Western Atlantic, with a summary of the recent species. Bull Mar Sci 15:737-796

Bowerbank JS (1869) A Monograph of the Siliceo-fibrous Sponges. Part I Proc Zool Soc Lond. 1869 (1), 66-100, pls III-VI

Brooke S, Young CM (2009) In situ measurement of survival and growth of Lophelia pertusa in the northern Gulf of Mexico. Mar Ecol Prog Ser 397:153-161. https://doi.org/10.3354/meps08344

Carpenter RC (1984) Predator and population density control of homing behavior in the Caribbean echinoid Diadema antillarum. Mar Biol 82(1):101-108. https://doi.org/10.1007/BF00392768

Cathalot C, Van Oevelen D, Cox TJS, Kutti T, Lavaleye M, Duineveld G, Meysman FJR (2015) Cold-water coral reefs and adjacent sponge grounds: hotspots of benthic respiration and organic carbon cycling in the deep sea. Front Mar Sci 2:37. https://doi.org/ 10.3389/fmars.2015.00037

Clark AH (1934a) Two new crinoids. Report on the collections obtained by the first Johnson-Smithsonian deep-sea expedition to the Puerto Rican deep. Smithson Misc Coll 91(4):1-5

Clark AH (1934b) A new starfish from Puerto Rico. Smithson Misc Coll 91(14):1-3

Crosse H, Fischer P (1861) Observations sur le genre Pleurotomaire, et description d'une deuxième espèce vivante appurtenant au même genre. J Conchyliol 9:155-167

Dahl MP, Pereyra RT, Lundälv T, André C (2012) Fine-scale spatial genetic structure and clonal distribution of the cold-water coral
Lophelia pertusa. Coral Reefs 31:1135-1148. https://doi.org/10. 1007/s00338-012-0937-5

Davies AJ, Wisshak M, Orr JC, Roberts JM (2008) Predicting suitable habitat for the cold-water coral Lophelia pertusa (Scleractinia), Deep-Sea Res Pt I: Oceanogr Res Pap 55(8):1048-1062. https://doi.org/10.1016/j.dsr.2008.04.010

Davies AJ, Guinotte JM (2011) Global Habitat Suitability for Framework-Forming Cold-Water Corals. PLoS ONE 6(4):e18483. https://doi.org/10.1371/journal.pone.0018483

Demopoulos AW, Bourque JR, Frometa J (2014) Biodiversity and community composition of sediment macrofauna associated with deep-sea Lophelia pertusa habitats in the Gulf of Mexico. DeepSea Res Pt I: Oceanogr Res Pap 93:91-103. https://doi.org/10. 1371/journal.pone.0018483

Donovan SK, Pawson DL (2008) A new species of the sessile crinoid Holopus d'Orbigny from the tropical western Atlantic, with comments on holopodid ecology (Echinodermata: Crinoidea: Holopodidae). Zootaxa 1717:31-38. https://doi.org/10.11646/zootaxa. 1717.1.3

Doughty CL, Quattrini AM, Cordes EE (2014) Insights into the population dynamics of the deep-sea coral genus Paramuricea in the Gulf of Mexico. Deep Sea Res II 99:71-82. https://doi.org/10. 1016/j.dsr2.2013.05.023

Etnoyer PJ, Shirley TC, Lavelle KA (2011) Deep Coral and Associated Species Taxonomy and Ecology (DeepCAST) II Expedition Report. NOAA Technical Memorandum NOS NCCOS 137. NOAA/NOS Center for Coastal Environmental Health and Biomolecular Research, Charleston, SC. 42 pp

Etnoyer PJ, Wickes LN, Silva M, Dubick JD, Balthis L, Salgado E, MacDonald IR (2016) Decline in condition of gorgonian octocorals on mesophotic reefs in the northern Gulf of Mexico: before and after the Deepwater Horizon oil spill. Coral Reefs 35(1):7790. https://doi.org/10.1007/s00338-015-1363-2

Fisher CR, Hsing PY, Kaiser CL, Yoerger DR, Roberts HH, Shedd WW, Cordes EE, Shank TM, Berlet SP, Saunders MG, Larcom EA, Brooks JM (2014) Footprint of Deepwater Horizon blowout impact to deep-water coral communities. Proceedings of the National Academy of Sciences 111(32):11744-11749. https://doi. org/10.1073/pnas.1403492111

Fischer P, Bernardi AC (1856) Description d'un Pleurotomaire vivante. J. Conchyliol. 5, 160-166, plate 5

Freiwald A, Fosså JH, Grehan A, Koslow T, Roberts JM (2004) Coldwater Coral Reefs. UNEP-WCMC, Cambridge, UK

Girard F, Fu B, Fisher CR (2016) Mutualistic symbiosis with ophiuroids limited the impact of the Deepwater Horizon oil spill on deep-sea octocorals. Mar Ecol Prog Ser 549, 89-98. http://www. int-res.com/articles/meps_oa/m549p089.pdf

Girard F, Fisher CR (2018) Long-term impact of the Deepwater Horizon oil spill on deep-sea corals detected after seven years of monitoring. Biol Cons 225:117-127. https://doi.org/10.1016/j.biocon. 2018.06.028

Grange KR (1991) Mutualism between the antipatharian Antipathes fiordensis and the ophiuroid Astrobrachion constrictum in New Zealand fjords. Hydrobiologia 216-217:297-303

Grasmueck M, Eberli GP, Viggiano DA, Correa T, Rathwell G, Luo J (2006) Autonomous underwater vehicle (AUV) mapping reveals coral mound distribution, morphology, and oceanography in deep water of the Straits of Florida. Geophys Res Lett 33(23):1-6. https://doi.org/10.1029/2006GL027734

Grasshoff M (1977) Die Gorgonarien des östlichen Nordatlantik und des Mittelmeeres III. Die Familie Paramuriceidae (Cnidaria, Anthozoa). "Meteor" Forsch.-Ergebnisse, Reihe D. 27: 5-76. http://pascal-francis.inist.fr/vibad/index.php?action=getRecordD etail\&idt=PASCAL7850271056 
Hebbeln D, da Costa Portilho-Ramos R, Wienberg C, Titschack J (2019) The fate of cold-water corals in a changing world: a geological perspective. Front Mar Sci 6(119). https://doi.org/10.3389/ fmars.2019.00119

Hourigan TF, Etnoyer PJ, Cairns SD (2017) The state of deep-sea coral and sponge ecosystems of the United States. NOAA Tech. Mem. NMFS-OHC-4. Silver Spring, MD. 467 pp

James NP, Ginsburg RN (1979) The seaward margin of Belize barrier and atoll reefs: morphology, sedimentology, organism distribution, and late Quaternary history. Special pub 3 of the Int. Ass. of Sedimentologists. Blackwell Scientific, Oxford. 207 pp

Jangoux M, Lawrence JM (1982) Echinoderm Nutrition. A. A. Balkema, Rotterdam

Johnson JY (1861) On the sea-anemones of Madeira. Proc. Zool. Soc. Lond. 1861, 298-306, figs. 1-4

Kahn AS, Ruhl HA, Smith KL Jr (2012) Temporal changes in deep-sea sponge populations are correlated to changes in surface climate and food supply. Deep-Sea Res I 70:36-41. https://doi.org/10. 1016/j.dsr.2012.08.001

Kuhnz LA, Ruhl HA, Huffard CL, Smith KL Jr (2014) Rapid changes and long-term cycles in the benthic megafaunal community observed over 24 years in the abyssal northeast Pacific. Progr Oceanogr 124:1-11. https://doi.org/10.1016/j.pocean.2014.04. 007

Larsson AI, Lundälv T, van Oevelen D (2013) Skeletal growth, respiration rate and fatty acid composition in the cold-water coral Lophelia pertusa under varying food conditions. Mar Ecol Prog Ser 483:169-184. https://doi.org/10.3354/meps 1 0284

Larsson AI, van Oevelen D, Purser A, Thomsen L (2013b) Tolerance to long-term exposure of suspended benthic sediments and drill cuttings in the cold-water coral Lophelia pertusa. Mar Pollut Bull 70(1-2):176-188. https://doi.org/10.1016/j. marpolbul.2013.02.033

Lavelle K (2012). Epifaunal assemblages on deep-water corals in Roatan, Honduras. [master's thesis]. [Corpus Christi (TX)]: Texas A\&M University-Corpus Christi.

Lemaitre R, Felder DL, Poupin J (2017) - Discovery of a new micro-pagurid fauna (Crustacea: Decapoda: Paguridae) in the Lesser Antilles. Caribbean Sea Zoosystema 39(2):151-195. https://doi.org/10.5252/z2017n2a1

Linnaeus C (1758) Systema Naturae per regna tria naturae, secundum classes, ordines, genera, species, cum characteribus, differentiis, synonymis, locis. Editio decima, reformata $\left[10^{\text {th }}\right.$ revised edition], vol. 1. Holmiae [Stockholm]: Laurentius Salvius.

Linnaeus C (1767) Systema naturae per regna tria naturae: secundum classes, ordines, genera, species, cum characteribus, differentiis, synonymis, locis. Ed. 12. 1., Regnum Animale. 1 \& 2. Holmiae [Stockholm]: Laurentii Salvii. pp. 1-532 [1766] pp. 533-1327 [1767]

Lyman T (1872) Note sur les Ophiurides et Euryales qui se trouvent les collections de Muséum d'Histoire Naturelle de Paris. Annal Sci Nat, ser 5, Zool. 16(4), 3-8

Mah C, Nizinski M, Lundsten L (2010) Phylogenetic revision of the Hippasterinae (Goniasteridae; Asteroidea): systematics of deep-sea corallivores, including one new genus and three new species. Zool J Linn Soc 160(2):266-301. https://doi.org/10. 1111/j.1096-3642.2010.00638.x

Messing, C. G., Neumann, A. C., \& Lang, J. C. (1990). Biozonation of deep-water lithoherms and associated hardgrounds in the northeastern Straits of Florida. Palaios 5(1), 15-33. https:// www.jstor.org/stable/3514994

Milne Edwards H, Haime J (1850) Classification of polypi. A monograph of the British fossil corals 1: viii-lxxxv. London: Palaeontographical Society of London
NOAA (2013) Multibeam Report for FK008-T, a website for data from hydrographic surveys of Isla Roatan aboard RV Falkor 008-T. National Geophysical Data Center, National Centers for Environmental Information. https://www.ngdc.noaa.gov/ships/ falkor/FK008-T_mb.html

NOAA (2019) Submersible dives since 1964, a spatial data layer in the Southeast Deep Coral Initiative (SEDCI) Digital Atlas, A Shuler and PJ Etnoyer, eds

Orbigny AD' (1837) Mémoire sur une seconde espèce vivante de la familie des Crinoïdes ou Encrines, servant de type au nouveau genre Holope (Holopus). Magasin de Zoologie, 7ème année, 10:1-8, pl. 3

Osterloff, J., Nilssen, I., Järnegren, J., Van Engeland, T., BuhlMortensen, P., \& Nattkemper, T. W. (2019). Computer vision enables short- and long-term analysis of Lophelia pertusa polyp behaviour and colour from an underwater observatory. Nature Sci Rep 9(6578). https://doi.org/10.1038/s41598-019-41275-1

Philippi RA (1845) Beschreibung einiger neuer Echinodermen nebst kritischen Bemerckungen über einige weniger bekannte Arten. Arch f Naturges 11:344-359

Pourtalès LF de (1868) Contributions to the fauna of the Gulf Stream at great depths. Bull Mus Comp Zool 1(6):103-142

Pourtalès LF de (1871) Deep-sea corals. Bull Mus Comp Zool 2(4), $1-93$, pls. $1-8$

Pourtalès LF de (1878) Corals. In: Reports on the dredging operations of the U.S. Coast Survey Steamer "Blake". Bull Mus Comp Zool 5, 197-212, pl. 1

Pourtalès LF de (1880) Report on the corals and Antipatharia. Reports on the results of dredging, under the supervision of Alexander Agassiz, in the Caribbean Sea, 1878-79, by the United States coast survey steamer "Blake", commander J.R. Bartlett, U.S.N., commanding. VI. Bull Mus Comp Zool 6(4), 95-120, pls. 1-3

Pratt A, Baldwin CC, Vecchione M (2019) Octopods of deep reefs off Curacao, southern Caribbean, including description of one newly discovered species. Bull Mar Sci 96(2):297-308. https://doi.org/ 10.5343/bms.2019.0040

Purser A (2015) A time series study of Lophelia pertusa and reef megafauna responses to drill cuttings exposure on the Norwegian margin. PLoS ONE 10(7):e0134076. https://doi.org/10.1371/journal. pone. 0134076

Quattrini AM, Gómez CE, Cordes EE (2017) Environmental filtering and neutral processes shape octocoral community assembly in the deep sea. Oecologia 183(1):221-236. https://doi.org/10.1007/ s00442-016-3765-4

Ramiro-Sánchez B, González-Irusta JM, Henry LA, Cleland J, Yeo I, Xavier JR, Carreiro-Silva M, Sampaio Í, Spearman J, Victorero L, Messing CG, Kazandis G, Roberts JM, Murton B (2019) Characterization and mapping of a deep-sea sponge ground on the Tropic Seamount (northeast tropical Atlantic): implications for spatial management in the high seas. Front Mar Sci 6(278). https://doi. org/10.3389/fmars.2019.00278/full

Reed JK, Weaver DC, Pomponi SA (2006) Habitat and fauna of deepwater Lophelia pertusa coral reefs off the southeastern US: Blake Plateau, Straits of Florida, and Gulf of Mexico. Bull Mar Sci 78(2):343-375

Reed JK, Messing C, Walker BK, Brooke S, Correa TB, Brouwer M, Udouj T, Farrington S (2013) Habitat characterization, distribution, and areal extent of deep-sea coral ecosystems off Florida. Southeastern USA Carib J Sci 47(1):13-30

Richardson PL (2005) Caribbean Current and eddies as observed by surface drifters. Deep-Sea Res II 52:429-463. https://doi.org/10. 1016/j.dsr2.2004.11.001

Roberts JM, Wheeler AJ, Freiwald A (2006) Reefs of the deep: the biology and geology of cold-water coral ecosystems. Science 312:543-547. https://doi.org/10.1126/science.1119861 
Rosencrantz E, Mann P (1991) SeaMARC II mapping of transform faults in the Cayman Trough. Caribbean Sea Geology 19(7):690-693

Ross SW, Brooke S, Quattrini AM, Rhode M, Watterson JC (2015) A deep-sea community, including Lophelia pertusa, at unusually shallow depths in the western North Atlantic Ocean off northeastern Florida. Mar Biol 162(3):635-648. https://doi.org/10.1007/ s00227-015-2611-2

Santodomingo N, Reyes J, Flórez P, Chacón-Gómez IC, van Ofwegen LP, Hoeksema BW (2013) Diversity and distribution of azooxanthellate corals in the Colombian Caribbean. Mar Biodivers 43:722. https://doi.org/10.1007/s12526-012-0131-6

Schmidt O (1870) Grundzüge einer Spongien-Fauna des atlantischen Gebietes. Leipzig: Wilhelm Engelmann. iii-iv, 1-88, pls I-VI

Stewart BG (1998) Can a snake star earn its keep? Feeding and cleaning behaviour in Astrobrachion constrictum (Farquhar) (Echinodermata: Ophuroidea), a euryalid brittle-star living in association with the black coral Antipathes fiordensis (Grange 1990). J Exp Biol \& Ecol 221:173-189

Stimpson W (1871) Preliminary report on the Crustacea dredged in the Gulf Stream in the Straits of Florida, by L.F. de Pourtalès, Assist. U.S. Coast Survey. Bull Mus Comp Zool 2:109-160

Stutchbury S (1841) Description of a new sponge from Barbados. Proc Roy Soc (b) 9:86-87

Syverson VJ, Messing CG, Stanley K, Baumiller TK (2014) Growth, injury, and population dynamics in the extant cyrtocrinid Holopus mikihe (Crinoidea, Echinodermata) near Roatán. Honduras Bull Mar Sci 91(1):47-61. https://doi.org/10.5343/bms.2014.1061
Tornabene L, Van Tassell JL, Gilmore RG, Robertson DR, Young F, Baldwin CC (2016) Molecular phylogeny, analysis of discrete character evolution, and submersible collections facilitate a new classification for a diverse group of gobies (Teleostei: Gobiidae: Gobiosomatini: Nes subgroup), with descriptions of nine new species. Zool J Linn Soc 2016. https://doi.org/10.1111/ zoj.12394

Tornabene L, Robertson DR, Baldwin CC (2018) A new species of Lipogramma from the deep reefs of Roatan, Honduras (Teleostei, Grammatidae). ZooKeys 809:79-95. https://doi.org/10.3897/ zookeys.809.29280

Veitch MA, Baumiller TK (2021) Low predation intensity on the stalked crinoid Democrinus sp. (Echinodermata) in Roatán, Honduras reveals deep water as likely predation refuge. Bull Mar Sci 97(1):107-128. https://doi.org/10.5343/bms.2020.0024

Verrill AE (1894) Descriptions of new species of starfishes and ophiurans, with a revision of certain species formerly described; mostly from the collections made by the United States Commission of Fish and Fisheries. Proceedings of the United States National Museum. 17(1000), 245-297. http://www.biodiversitylib rary.org/page/15675247

Wangensteen OS, Turon X, Garcia-Cisneros A, Recasens M, Romero J, Palacin C (2011) A wolf in sheep's clothing: carnivory in dominant sea urchins in the Mediterranean. Mar Ecol Prog Ser 441:117-128. https://doi.org/10.3354/meps09359

Publisher's note Springer Nature remains neutral with regard to jurisdictional claims in published maps and institutional affiliations. 